\title{
Microwave-assisted synthesis of graphene nanocomposites: recent developments on lithium-ion batteries
}

This article was published in the following Dove Press journal:

Reports in Electrochemistry

31 July 2015

Number of times this article has been viewed

\section{Weiwei Sun \\ $\mathrm{Hao} \mathrm{Li}$ \\ Yong Wang}

Department of Chemical Engineering, School of Environmental and

Chemical Engineering, Shanghai University, Shanghai, People's

Republic of China
Correspondence: Yong Wang Department of Chemical Engineering, School of Environmental and Chemical Engineering, Shanghai University, Shangda Road 99, Shanghai 200444, People's Republic of China

Tel +86 2I 66I37723

$\mathrm{Fax}+862166137725$

Email yongwang@shu.edu.cn
Abstract: Lithium ion battery (LIB) is a popular power source for various portable mobile devices and even electrical vehicles. Graphene-based composites are important electrodes for LIBs due to their high-capacity, long cycle life, and impressive high-rate capability. Microwaveassisted synthesis is a promising approach to prepare graphene-based composites owing to its fast, energy-efficient features. By varying microwave irradiation conditions, surface functionality and morphology control can be tuned for either graphene or the introduced secondary phase in the graphene-based composites. When used for LIBs, the graphene-based composites can offer a variety of merits for the improved electrochemical properties such as facilitated lithium diffusion/ storage and the increased mechanical stability of the electrodes during repetitive cycling. This article reviews the recent progress of microwave-assisted synthesis of graphene-based electrodes and their applications for LIBs. Graphene-supported transitional metal oxides anodes (Li-storage conversion mechanism), tin/germanium/silicon based anodes (lithium alloy mechanism), metal sulfides (conversion or lithium alloy mechanism), lithium-titanium-oxide-based anodes (lithium insertion mechanism), and graphene-decorated lithium iron phosphate cathodes are reviewed with more emphasis because these materials have attracted significant research concerns. The effect of microwave irradiation and the resultant structure and size control of graphene-based composites on their electrochemical properties is also elucidated.

Keywords: electrode, graphene, lithium ion batteries, microwave irradiation, nanocomposites

\section{Introduction}

With the development of electrical energy-storage materials to meet the increasing demand for the ever-growing energy consumption, lithium-ion battery (LIB), with excellence in terms of high energy density, no memory effect, long cycle life, and environmental friendliness, has been an attractive power source for portable mobile devices and stationary energy storage. ${ }^{1-4}$ As the commercial anode for LIBs, graphite gradually cannot satisfy the requirements of the ever-growing advanced high-power LIBs and new anode materials with higher energy density and power density must be explored..$^{5-8}$ Since the discovery in 2004, graphene has attracted significant research concerns for various energy-relative applications including LIBs, ${ }^{9-11}$ solar cells, ${ }^{12-14}$ supercapacitors, ${ }^{15-17}$ and fuel cells. ${ }^{18-21}$ This is largely ascribed to its intriguing properties associated with the unique single-atom layered structure such as a large theoretical specific surface area of $2,600 \mathrm{~m}^{2} \mathrm{~g}^{-1}, 22$ highly flexible but robust mechanical structure, and fast electronic conduction. As an anode for LIBs, graphene was reported with a reversible capacity of $\sim 400-1,100 \mathrm{mAh} \mathrm{g}^{-1},{ }^{23-26}$ and its unsatisfactory cyclability has been mainly ascribed to its heavy agglomeration during cycling, 
which leads to the loss of promising properties relative to the atomic-thickness structure. An effective strategy is to introduce the secondary phase to the graphene, which acts as a spacer to separate few-layer graphene nanosheets (GNS) and prevent their restacking to graphite platelets. ${ }^{27-29}$ The introduced component is usually also highly active for lithium-ion storage, and therefore, there is no capacity loss for the resultant composites. Moreover, the presence of graphene is also very beneficial for the improvement of the electrical conductivity and mechanical stability to the introduced secondary phase. As a result, graphenesupported composites can exhibit synergetic effect with respect to lithium-ion storage properties and achieve better electrochemical performance, especially long cycle life and impressive high-rate capability. ${ }^{30}$

GNS used for fabrication of lithium ion anode materials were mostly synthesized through the chemical oxidation and reduction approach. The exfoliation and reduction of graphene oxide (GO) is the most important step to obtain GNS with suitable functionalities and reduction extents, which strongly affect the electrochemical properties of graphene or graphene-based composite electrodes. However, the exfoliation and reduction of GO rely heavily on the usage of strong reducing agents or a very high temperature. Most of these approaches are complicated, energy, and cost intensive. Recently, microwave exfoliation has been proved to be an attractive method for graphene preparation ${ }^{31-33}$ because it is a facile, time-efficient, and cost-effective process. Besides, the obtained graphene via microwave-assisted methods can exhibit larger average size, higher quality with residual functional groups, and better electrochemical properties for LIBs compared with those prepared from conventional methods. $^{34-36}$

Microwaves have been widely used in industrial applications such as food processing ${ }^{37,38}$ and industrial materials..$^{39,40}$ Motivated by its advantages of facile, fast, secure, controllable, and energy-saving characteristics, microwave-assisted technique has achieved rapid development in the field of materials science. ${ }^{41,42}$ Microwave-assisted techniques such as solid-state microwave irradiation, microwave-assisted solvothermal/hydrothermal process can provide simple and fast routes to synthesize nanomaterials without high temperature or high pressure. Furthermore, the microwave technique is particularly useful for a large-scale synthesis without complicated preparation conditions. ${ }^{43-46}$ The rapid transfer of energy and fast decomposition of the precursors provided by microwave source would result in highly effective local reaction temperatures and significant enhancement in reaction rates.
Besides, the microwave technique can provide an effective way to control particle size distribution and macroscopic morphology during the synthesis process because it can heat a substance uniformly and therefore a more homogeneous nucleation environment and a shorter crystallization time can be achieved compared to conventional heating.

In this review, we aim to investigate the mechanism of microwave-assisted syntheses of graphene and graphenebased nanocomposites, and summarize the recent development of graphene-supported nanocomposites for applications as electrodes for LIBs. Various types of graphene-based nanomaterials: mainly graphene-based transitional metal oxide anodes, tin/germanium/silicon based anodes, metal sulfides anodes, lithium-titanium-oxide-based anodes and graphene-decorated lithium iron phosphate cathodes are presented and discussed with respect to their morphological and size control in the microwave-assisted preparation process and their relation to the resultant lithium storage properties.

\section{Mechanism of microwave-assisted syntheses}

Microwave irradiation is an electromagnetic irradiation in the range of wavelengths from $0.01 \mathrm{~m}$ to $1 \mathrm{~m}$ with corresponding frequency range from $300 \mathrm{MHz}$ to $300 \mathrm{GHz} .{ }^{47} \mathrm{The}$ domestic microwave generally owns a frequency of $2.45 \mathrm{GHz}$ (a wavelength of $12.25 \mathrm{~cm}$ ), while the industrial microwave usually owns two frequencies of $915 \mathrm{MHz}$ and $2.45 \mathrm{GHz} \cdot{ }^{37}$ Microwave has been widely used for heating those materials, which can absorb microwave energy and convert it into heat. In the presence of moisture or water, dielectric heating happens due to the dipolar nature of water. These permanently polarized dipolar molecules could rearrange in the direction of the electric field at a high speed, which would cause internal friction of molecules and further result in the volumetric heating of the whole material. Besides the dipolar mechanism, microwave heating may also occur due to the ionic mechanism, and oscillatory migration of ions in the material would generate heat under a high-frequency oscillating electric field. ${ }^{48}$ Consequently, microwave-assisted technology can provide a fast and effective approach to heat the material/system homogeneously from the interior. In contrast, traditional heating system, in which heat is transferred from the surface toward the center of the material under the help of heating mantle, water/oil bath or other external heat source, is relatively slow and inefficient.

GNS are usually obtained from graphite or GO, which is prepared by a modified Hummer's method. ${ }^{49-51}$ The reduction of GO is usually carried out by chemical methods in the 
presence of various hazardous reduction agents such as hydrazine and $\mathrm{NaBH}_{4}$. In comparison, thermal treatment is a green method because no hazardous reduction agents are used. Instead of the conventional preparation of graphene in traditional heating system (furnace or oil bath), the ecofriendly microwave-assisted method has attracted increasing attentions in which the microwave-assisted solvothermal/ hydrothermal methods can be adopted to treat $\mathrm{GO}^{52,53}$ or natural graphite ${ }^{54-57}$ in a microwave oven or microwave plasmaenhanced chemical vapor deposition (MPCVD) system..$^{58-60}$ It is worth noting that the microwave exfoliation is an attractive and effective method for graphene synthesis from GO, in which GO is exfoliated with nontoxic solvents within a short reaction time of $1-15$ minutes at a relatively low temperature range of $180^{\circ} \mathrm{C}-300^{\circ} \mathrm{C} .5^{52,53}$ It was reported that the stable graphene suspension could be obtained from the GO suspension in an alkaline medium $(\mathrm{pH} \approx 10)$ or polar solvents ( $\mathrm{N}, \mathrm{N}$-dimethylformamide, ethanol, 1-butanol, and water) in a facile microwave-assisted solvothermal process. ${ }^{61,62}$ Besides, the water-soluble polymer-grafted graphene sheets were prepared from GO in a household microwave oven at a power of $450 \mathrm{~W}$ for 4 minutes. ${ }^{63}$ The synthesis of threedimensional (3D) nanostructure of "graphene nano-cup" anchored on the few layered graphene substrate ${ }^{64}$ under the microwave irradiation in a domestic microwave oven was reported by two steps: one-pot synthesis of graphene-coated metal nanoparticles anchored on the graphene sheets and the subsequent etching of metals. Furthermore, giant graphene sheets could be obtained by double microwave-assisted exfoliation of expandable graphite ${ }^{65}$ and highly hydrogenated graphene could be produced from GO by a one-step microwave irradiation process in hydrogen plasma, in which the deoxidation and concurrent hydrogenation were both achieved. ${ }^{66} \mathrm{~A}$ possible mechanism of graphene preparation by a microwave-assisted technology is illuminated in Figure 1. The microwave irradiation provides high local temperature and pressure atmosphere, and energy is transferred directly into the GO interior. Heat is produced from the interaction of irradiation with the polar bond of oxygen-containing functional groups on the surface and edge of GO sheets. Besides, the interaction between polar solvent and surface oxides on GO sheets is an important factor to determine the uniformity of deposits. Furthermore, the functional groups on the surface of GO are effectively reduced, and the reduction degree of graphene sheets is further improved.

The microwave-assisted technology for the synthesis of graphene has several obvious advantages. First, the microwave-assisted process is time-efficient without complicated synthesis procedure. Second, such process is cost-effective as the quantity of the used chemicals is greatly reduced compared to conventional approaches. Third, the average size of the obtained graphene from microwave-assisted technology can be ten times larger than those prepared by the conventional heating method. Finally, the graphene products from microwave-assisted technology are of high quality with controlled structure and residual functional groups.

Until now, microwave irradiation has been suggested as an effective tool to obtain carbon-relative composites with uniform dispersion and size and morphology control, ${ }^{67-69}$ because the microwave energy allows rapid heating and extremely rapid rate of crystallization to produce the desired nanocrystalline products. Meanwhile, during the microwave-assisted synthesis process, it is possible to control the growth of the favorable crystallographic plane by varying reaction time and the relative concentrations of different organic surfactants. Furthermore, the obtained nanostructures would extend from small spherical nuclei to short nanorod or nanosheet. ${ }^{70-72}$ As a result, various graphenebased nanocomposites with controlled size and shape, such as particle/crystal-on-sheet, nanorod/nanofiber-on-sheet, and nanosheet-on-sheet, can be obtained with the help of ecofriendly microwave-assisted technology, as illuminated in Figure 1. It is worthy noting that the hydrothermal/ solvothermal processes operated in a single-mode microwave reaction or a multimode household microwave oven are the most used technology for the microwave-assisted synthesis of graphene-based nanocomposites. Nonuniform microwave is offered from multimode domestic microwave oven, in which

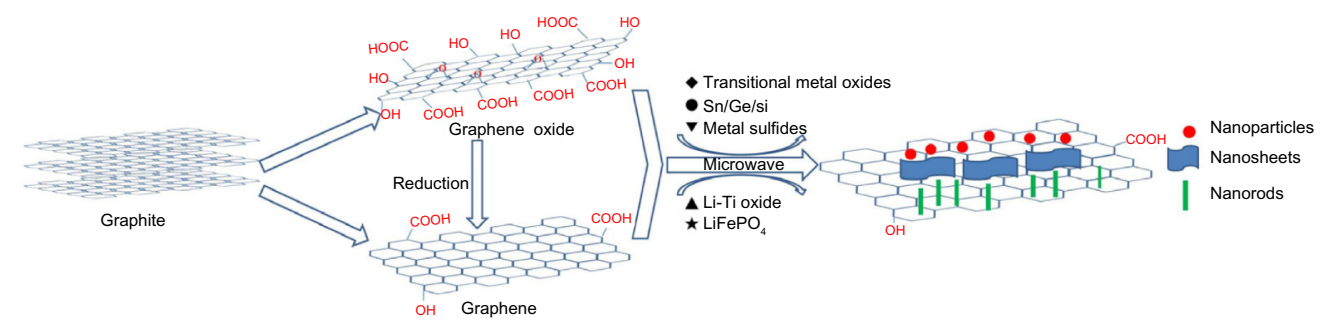

Figure I Schematic illustration of the synthesis of graphene and graphene-based composites with the assistance of microwave irradiation. 
there is considerable variation in the microwave intensity throughout the reactor chamber. Moreover, the multimode domestic microwave oven can only roughly provide the time and several stages of power control (such as high, medium, low). In comparison, very uniform microwave can be generated in the specialized single-mode microwave reactor with stable microwave intensity in the chamber in which power, temperature, and time can be fine-tuned with continuous magnetic stirring. Therefore, the reaction environment is more uniform in the single-mode microwave reactor and better size and shape control should be achieved.

\section{GNS-supported transitional metal oxide anodes}

The microwave irradiation method has been applied for the synthesis of GNS-supported transitional metal oxide electrodes such as $\mathrm{Co}_{3} \mathrm{O}_{4}-\mathrm{GNS},{ }^{73-77} \mathrm{CuO}-\mathrm{GNS},{ }^{78-83}$ and $\mathrm{Fe}_{\mathrm{x}} \mathrm{O}_{\mathrm{y}}$-GNS. ${ }^{84-89}$ All these transitional metal oxides have approximately two to three times larger theoretical capacities than commercial graphite anode based on a well-known conversion mechanism of lithium storage. Lithium can reduce metal oxides to metal and form lithium oxide, and this reaction is reversible. The morphologies and lithium-storage properties of various graphene-supported transitional metal oxide anodes are summarized in Table 1. Among these GNSsupported transitional metal oxide anodes, $\mathrm{Co}_{3} \mathrm{O}_{4}$-GNS tends to form a particle-on-nanosheet morphology under microwave irradiation. ${ }^{73-76}$ As reported by Wang et al, ${ }^{77}$ two-dimensional (2D) porous $\mathrm{Co}_{3} \mathrm{O}_{4}$ nanosheets were obtained by a microwave solvothermal process at $180^{\circ} \mathrm{C}$ for 5 minutes (pressure: $\sim 7.5$ bar) in a single-mode microwave reactor (Nova, EU Microwave Chemistry, Shanghai, People's Republic of China). As shown in Figure 2, these porous $\mathrm{Co}_{3} \mathrm{O}_{4}$ nanosheets have pore sizes of 60-100 nm and a thickness around $100 \mathrm{~nm}$. After stacking with graphene, the $\mathrm{Co}_{3} \mathrm{O}_{4}$-GNS composite can form a sheet-on-sheet composite structure. ${ }^{77}$ The sheet-on-sheet composite shows superior Li-ion storage performances. Initial reversible charge capacity of $1,235 \mathrm{mAh} \mathrm{g}^{-1}$ is delivered, which decreases to $1,065 \mathrm{mAh} \mathrm{g}^{-1}$ after 30 cycles. This capacity is larger than those of GO or GNS, and even the theoretical value of pristine $\mathrm{Co}_{3} \mathrm{O}_{4}\left(890 \mathrm{mAh} \mathrm{g}^{-1}\right)$. The composite also exhibits an impressive good high-rate capability (a reversible capacity of $931 \mathrm{mAh} \mathrm{g}^{-1}$ at a large current rate of $5 \mathrm{C}[4,450$ $\mathrm{mA} \mathrm{g}^{-1}, 5 \mathrm{C}$ represents the current at which the cell capacity is charged/discharged in $1 / 5 \mathrm{~h}]$ ).

Synthesized by the microwave-assisted technology, GNS-supported copper oxides can exhibit a variety of morphologies including zero-dimensional (0D) nanoparticle ${ }^{78 /}$ nanosphere, ${ }^{79,80}$ one-dimensional (1D) nanowire ${ }^{81} /$ fusiform, ${ }^{82}$ and 2D nanolea ${ }^{83} /$ nanosheet $^{82}$ morphologies. Among them, GNS-supported copper oxides with higher dimensional (1D and 2D) ${ }^{81-83}$ or core-shell morphology ${ }^{79}$ exhibit better electrochemical performance. By a fast single-mode microwave hydrothermal method, the GNS-supported sheet-like or fusiform-like $\mathrm{CuO}$ morphologies were obtained by varying the reaction temperature of microwave heating. As shown in Figure $3 \mathrm{~A}-\mathrm{C},{ }^{82} \mathrm{CuO}-\mathrm{GNS}$ sheet-on-sheet product was prepared at $170^{\circ} \mathrm{C}$ with $\mathrm{CuO}$ nanosheet of $0.3-0.5 \mu \mathrm{m}$ in size, while the CuO-GNS fusiform-on-sheet material was obtained at a lower temperature of $110^{\circ} \mathrm{C}$ with fusiform $\mathrm{CuO}$ product owning the length around $0.4-0.8 \mu \mathrm{m}$ and narrow tips. Figure $3 \mathrm{D}$ shows the electrochemical performance of the above two CuO-GNS composites in comparison with the physical mixture of $\mathrm{CuO}$ and GNS. Reversible charge capacities of 801 and $666 \mathrm{mAh} \mathrm{g}^{-1}$ can be retained after 40 cycles for graphene-supported $\mathrm{CuO}$ nanosheet and fusiform composites, respectively. These reversible capacities are substantially larger than that of CuO-GNS (431 $\mathrm{mAh} \mathrm{g}^{-1}$ ) by a physical mixture after the same cycle numbers. As shown in Figure 3E, the graphene-supported $\mathrm{CuO}$ nanosheet composite exhibits an excellent rate capability with initial charge capacities of 981, 925, and $846 \mathrm{mAh} \mathrm{g}^{-1}$ at 1,2 , and $5 \mathrm{C}$, respectively (1 $\mathrm{C}=700 \mathrm{~mA} \mathrm{~g}^{-1}$ ).

The $\mathrm{Fe}_{2} \mathrm{O}_{3}$-GNS composite with porous nanorod-on-sheet morphology was synthesized by a solvothermal process in a microwave oven. ${ }^{84}$ The composite delivers a high reversible initial capacity of $1,016 \mathrm{mAh} \mathrm{g}^{-1}$ at $0.1 \mathrm{~A} \mathrm{~g}^{-1}\left(508 \mathrm{mAh} \mathrm{g}^{-1}\right.$ at $2 \mathrm{~A} \mathrm{~g}^{-1}$ after 200 cycles). By comparison, the GNS-supported $\mathrm{Fe}_{2} \mathrm{O}_{3}$ nanoparticle composite ${ }^{85}$ obtained from the similar hydrothermal process in microwave oven exhibits better electrochemical properties with discharge capacities of 1,693, $1,142,1,120,1,098$, and $1,027 \mathrm{mAh} \mathrm{g}^{-1}$ in the first, tenth, 20th, 30th, and 50th cycles, respectively. A high capacity of $\sim 800 \mathrm{mAh} \mathrm{g}^{-1}$ is also observed at a current density of $800 \mathrm{~mA} \mathrm{~g}^{-1}$. Among the various GNS-supported $\mathrm{Fe}_{3} \mathrm{O}_{4}$ composites, $\mathrm{Fe}_{3} \mathrm{O}_{4}$ has a trend to form a particle or a porous particle morphology by the microwave-assisted technology. ${ }^{86-89}$ As reported by $\mathrm{Yu}$ et al, a series of $\mathrm{Fe}_{3} \mathrm{O}_{4}$-GNS nanostructures were synthesized by a simple nonaqueous sol-gel approach in a single-mode microwave apparatus. ${ }^{88}$ With different compositional ratios of $\mathrm{Fe}_{3} \mathrm{O}_{4}$ and GNS, reaction temperature, and times, as well as the synthesis method (Hummer's method or modified Hummer's procedure) of GO reactant, the obtained $\mathrm{Fe}_{3} \mathrm{O}_{4}$-GNS composites exhibit different particle sizes on the surface of GNS. The cycling performances of GNS-supported $\mathrm{Fe}_{3} \mathrm{O}_{4}$ composites are very stable even at high current 
Table I Summary on the morphologies and electrochemical performances of graphene-supported transitional metal oxide anodes

\begin{tabular}{|c|c|c|c|}
\hline Composites & Morphologies & Electrochemical performances & Reference \\
\hline $3 \mathrm{D} \mathrm{Co} \mathrm{O}_{4} / \mathrm{GNS}$ & Nanoparticle-on-sheet & $\begin{array}{l}\text { An initial large discharge capacity of } \sim 900 \mathrm{mAh} \mathrm{g}^{-1} \text { at } 0.2 \mathrm{C} \text {, and the retained } \\
\text { capacity of } \sim 600 \mathrm{mAh} \mathrm{g}^{-1} \text { after } 50 \text { cycles }\end{array}$ & 73 \\
\hline $\mathrm{Co}_{3} \mathrm{O}_{4} / \mathrm{N}$-doped graphene & Nanoparticle-on-sheet & A reversible capacity of $\sim 910 \mathrm{mAh} \mathrm{g}^{-1}$ after 100 cycles at $100 \mathrm{~mA} \mathrm{~g}^{-1}$ & 74 \\
\hline $\mathrm{Co}_{3} \mathrm{O}_{4} / \mathrm{GNS}$ & Nanoparticle-on-sheet & A reversible capacity of $\sim 1,785 \mathrm{mAh} \mathrm{g}^{-1}$ after 90 cycles at $89 \mathrm{~mA} \mathrm{~g}{ }^{-1}$ & 75 \\
\hline $\mathrm{Co}_{3} \mathrm{O}_{4} / \mathrm{GNS}$ & Nanoparticle-on-sheet & $\begin{array}{l}\text { An initial large charge capacity of } \sim 934 \mathrm{mAh} \mathrm{g}^{-1} \text { at } 70 \mathrm{~mA} \mathrm{~g}^{-1} \text { and a high } \\
\text { retained capacity of } 650 \mathrm{mAh} \mathrm{g} \text { after } 50 \text { cycles at } 700 \mathrm{~mA} \mathrm{~g}^{-1}\end{array}$ & 76 \\
\hline $\mathrm{Co}_{3} \mathrm{O}_{4} / \mathrm{GNS}$ & Sheet-on-sheet & 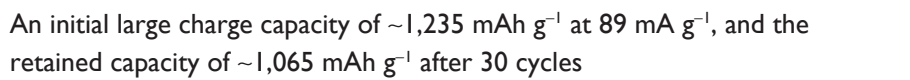 & 77 \\
\hline $\mathrm{CuO} / \mathrm{RGO}$ & Nanoparticle-on-sheet & 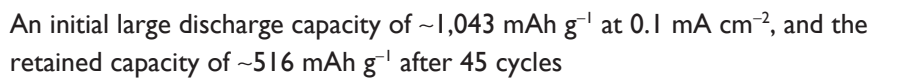 & 78 \\
\hline $\mathrm{CuO@Cu/RGO}$ & Nanoparticle-on-sheet & $\begin{array}{l}\text { An initial large charge capacity of } \sim 734 \mathrm{mAh} \mathrm{g}^{-1} \text { at } 50 \mathrm{~mA} \mathrm{~g}^{-1} \text {, and the retained } \\
\text { capacity of } \sim 842 \mathrm{mAh} \mathrm{g}^{-1} \text { after } 50 \text { cycles }\end{array}$ & 79 \\
\hline $\mathrm{CuO}-\mathrm{Cu}_{2} \mathrm{O} / \mathrm{GNS}$ & Nanosphere-on-sheet & A reversible capacity of $487 \mathrm{mAh} \mathrm{g}^{-1}$ retains after 60 cycles at $200 \mathrm{~mA} \mathrm{~g}^{-1}$ & 80 \\
\hline $\mathrm{CuO} / \mathrm{GNS}$ & Nanowire-on-sheet & A reversible capacity of $770 \mathrm{mAh} \mathrm{g}^{-1}$ retains after 100 cycles at $100 \mathrm{~mA} \mathrm{~g}^{-1}$ & 81 \\
\hline $\mathrm{CuO} / \mathrm{GNS}$ & Sheet-on-sheet & 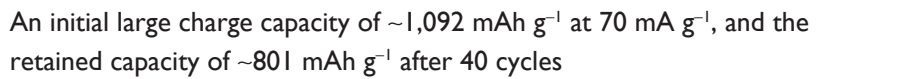 & 82 \\
\hline $\mathrm{CuO} / \mathrm{GNS}$ & Fusiform-on-sheet & $\begin{array}{l}\text { An initial large charge capacity of } \sim 956 \mathrm{mAh} \mathrm{g}^{-1} \text { at } 70 \mathrm{~mA} \mathrm{~g}^{-1} \text {, and the retained } \\
\text { capacity of } \sim 666 \mathrm{mAh} \mathrm{g}^{-1} \text { after } 40 \text { cycles }\end{array}$ & 82 \\
\hline $\mathrm{CuO} / \mathrm{GNS}$ & Nanoleaf-on-sheet & A reversible capacity of $600 \mathrm{mAh} \mathrm{g}^{-1}$ retains after 50 cycles at $100 \mathrm{~mA} \mathrm{~g}^{-1}$ & 83 \\
\hline $\mathrm{Fe}_{2} \mathrm{O}_{3} / \mathrm{N}$-doped graphene & Nanorod-on-sheet & $\begin{array}{l}\text { A stable capacity of } 508 \mathrm{mAh} \mathrm{g}^{-1} \text { at } 2 \mathrm{~A} \mathrm{~g}^{-1} \text { after } 200 \text { cycles, and an impressive } \\
\text { capacity of } 249 \mathrm{mAh} \mathrm{g}^{-1} \text { at } 20 \mathrm{~A} \mathrm{~g}^{-1} \text { after } 2,000 \text { cycles without capacity fading }\end{array}$ & 84 \\
\hline $\mathrm{Fe}_{2} \mathrm{O}_{3} / \mathrm{RGO}$ & Nanoparticle-on-sheet & $\begin{array}{l}\text { An initial large charge capacity of } \sim 1,227 \mathrm{mAh} \mathrm{g}^{-1} \text { at } 100 \mathrm{~mA} \mathrm{~g}^{-1} \text {, and the } \\
\text { retained capacity of } \sim 1,027 \mathrm{mAh} \mathrm{g^{-1 }} \text { after } 50 \text { cycles based on the mass of } \mathrm{Fe}_{2} \mathrm{O}_{3}\end{array}$ & 85 \\
\hline $\mathrm{Fe}_{3} \mathrm{O}_{4} / \mathrm{GNS}$ & Nanoparticle-on-sheet & $\begin{array}{l}\text { An initial large discharge capacity of } \sim 1,320 \mathrm{mAh} \mathrm{g}^{-1} \text { at } 0.1 \mathrm{C} \text {, and the retained } \\
\text { capacity of } \sim 650 \mathrm{mAh} \mathrm{g}^{-1} \text { after } 50 \text { cycles }\end{array}$ & 86 \\
\hline $\mathrm{Fe}_{3} \mathrm{O}_{4} / \mathrm{RGO}$ & $\begin{array}{l}\text { Nanoparticle-on-thin } \\
\text { layer }\end{array}$ & $\begin{array}{l}\text { A reversible capacity of } 612 \mathrm{mAh} \mathrm{g}^{-1} \text { at I C, with a Coulombic efficiency of } \\
98 \% \text { after } 50 \text { cycles }\end{array}$ & 87 \\
\hline $\mathrm{Fe}_{2} \mathrm{O}_{3} / \mathrm{RGO}$ & $\begin{array}{l}\text { Nanoparticle-on-thin } \\
\text { layer }\end{array}$ & $\begin{array}{l}\text { A reversible capacity of } 1,050 \mathrm{mAh} \mathrm{g}^{-1} \text { at } 100 \mathrm{~mA} \mathrm{~g}^{-1} \text {, and a reversible capacity } \\
\text { of } 500 \mathrm{mAh} \mathrm{g}^{-1} \text { at } 1,600 \mathrm{~mA} \mathrm{~g}^{-1}\end{array}$ & 88 \\
\hline $\mathrm{Fe}_{2} \mathrm{O}_{3} / \mathrm{GNS}$ & Rice-on-sheet & $\begin{array}{l}\text { An initial large discharge capacity of } \sim 1,184 \mathrm{mAh} \mathrm{g}^{-1} \text { at } 0.1 \mathrm{C} \text {, and the retained } \\
\text { capacity of } \sim 734 \mathrm{mAh} \mathrm{g}^{-1} \text { after } 40 \text { cycles }\end{array}$ & 89 \\
\hline $\mathrm{Fe}_{2} \mathrm{O}_{3} / \mathrm{GNS}$ & Nanoparticle-on-sheet & $\begin{array}{l}\text { An initial large discharge capacity of } \sim 1,120 \mathrm{mAh} \mathrm{g}^{-1} \text { at } 0.1 \mathrm{C} \text {, and the retained } \\
\text { capacity of } \sim 312 \mathrm{mAh} \mathrm{g}^{-1} \text { after } 40 \text { cycles }\end{array}$ & 89 \\
\hline $\mathrm{Mn}_{3} \mathrm{O}_{4} / \mathrm{GNS}$ & Nanoparticle-on-sheet & $\begin{array}{l}\text { A high reversible specific capacity of more than } 900 \mathrm{mAh} \mathrm{g}^{-1} \text { at } 40 \mathrm{~mA} \mathrm{~g}^{-1} \text { with } \\
\text { no capacity decay up to } 50 \text { cycles }\end{array}$ & 90 \\
\hline $\mathrm{MoO}_{3} / \mathrm{GNS}$ & Nanobelt-on-layer & A reversible capacity of $172 \mathrm{mAh} \mathrm{g}^{-1}$ retained after 100 cycles at $100 \mathrm{~mA} \mathrm{~g}^{-1}$ & 91 \\
\hline $\mathrm{MoO}_{2} / \mathrm{GNS}$ & Nanoparticle-on-sheet & $\begin{array}{l}\text { An initial large discharge capacity of } \sim 1,296 \mathrm{mAh} \mathrm{g}^{-1} \text { at } 0.1 \mathrm{C} \text {, and the retained } \\
\text { capacity of } \sim 1,330 \mathrm{mAh} \mathrm{g}^{-1} \text { after } 100 \text { cycles }\end{array}$ & 92 \\
\hline $\mathrm{ZnO} / \mathrm{GNS}$ & Nanocrystal-on-sheet & A reversible capacity of $460 \mathrm{mAh} \mathrm{g}^{-1}$ retained after 50 cycles at I C & 93 \\
\hline
\end{tabular}

Abbreviations: GNS, graphene nanosheets; RGO, reduced graphene oxide.

density, which delivers high capacity of over $500 \mathrm{mAh} \mathrm{g}^{-1}$ at $1,600 \mathrm{~mA} \mathrm{~g}^{-1} \cdot{ }^{88}$ Moreover, the $\mathrm{Fe}_{2} \mathrm{O}_{3}$-GNS rice-on-sheet and particle-on-sheet nanocomposites were synthesized by singlemode microwave hydrothermal technique with and without $\mathrm{NH}_{4} \mathrm{H}_{2} \mathrm{PO}_{4}$, respectively, as shown in Figure 4A. ${ }^{89} \mathrm{The}_{2} \mathrm{Fe}_{3}$ nanorice is observed with a length of $200 \mathrm{~nm}$ and diameters in the range of $\sim 40 \mathrm{~nm}$ in the middle part to only $3-5 \mathrm{~nm}$ in the tip (Figure 4C), while the nanoparticle is nearly a nanocube-like morphology of $\sim 50-80 \mathrm{~nm}$ in size (Figure 4B). The $\mathrm{Fe}_{2} \mathrm{O}_{3}$ GNS rice-on-sheet composite exhibits large reversible charge capacities of 825,762 , and $633 \mathrm{mAh} \mathrm{g}^{-1}$ at large currents of 1 , 2 , and $5 \mathrm{C}\left(1 \mathrm{C}=1,000 \mathrm{~mA} \mathrm{~g}^{-1}\right)$ respectively. A high capacity of $582 \mathrm{mAh} \mathrm{g}^{-1}$ can be observed at $1 \mathrm{C}$ after 100 cycles. The rice-on-sheet composite also shows more stable cycle life and better high-rate performance than the particle-on-sheet composite (Figure 4D and E).

There are also several reports on GNS-supported other transitional metal oxides. Their electrochemical performances are summarized in Table 1. GNS-supported $\mathrm{Mn}_{3} \mathrm{O}_{4}$ particle composite was prepared by a microwave hydrothermal method..$^{90}$ It exhibits a high specific capacity of more than $900 \mathrm{mAh} \mathrm{g}^{-1}$ at $40 \mathrm{~mA} \mathrm{~g}^{-1}$ and no capacity fading up to 50 cycles. By a similar microwave hydrothermal process, the $\mathrm{MoO}_{3}$ nanobelt/graphene film was also reported by 


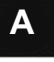

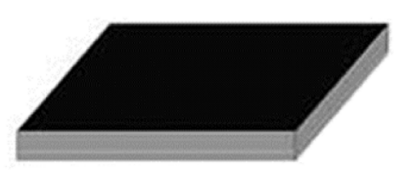

Graphite
Oxidation and exfoliation

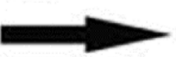

Graphene oxide nanosheet

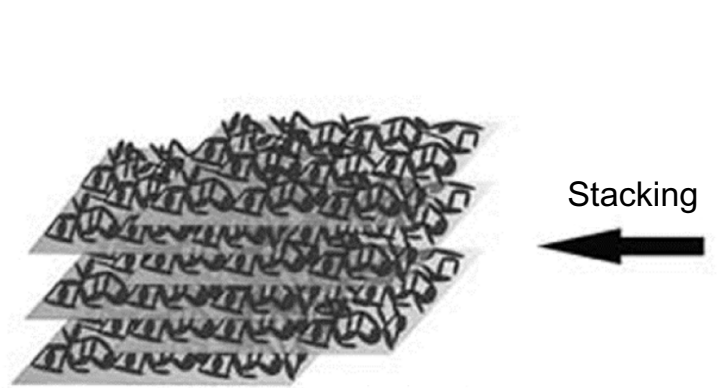

Alternatively stacked composite of $\mathrm{Co}_{3} \mathrm{O}_{4}$ sheet on graphene nanosheet

1) Microwave loading $\mathrm{Co}(\mathrm{OH})_{2}$

2) Pyrolysis reduction and calcination
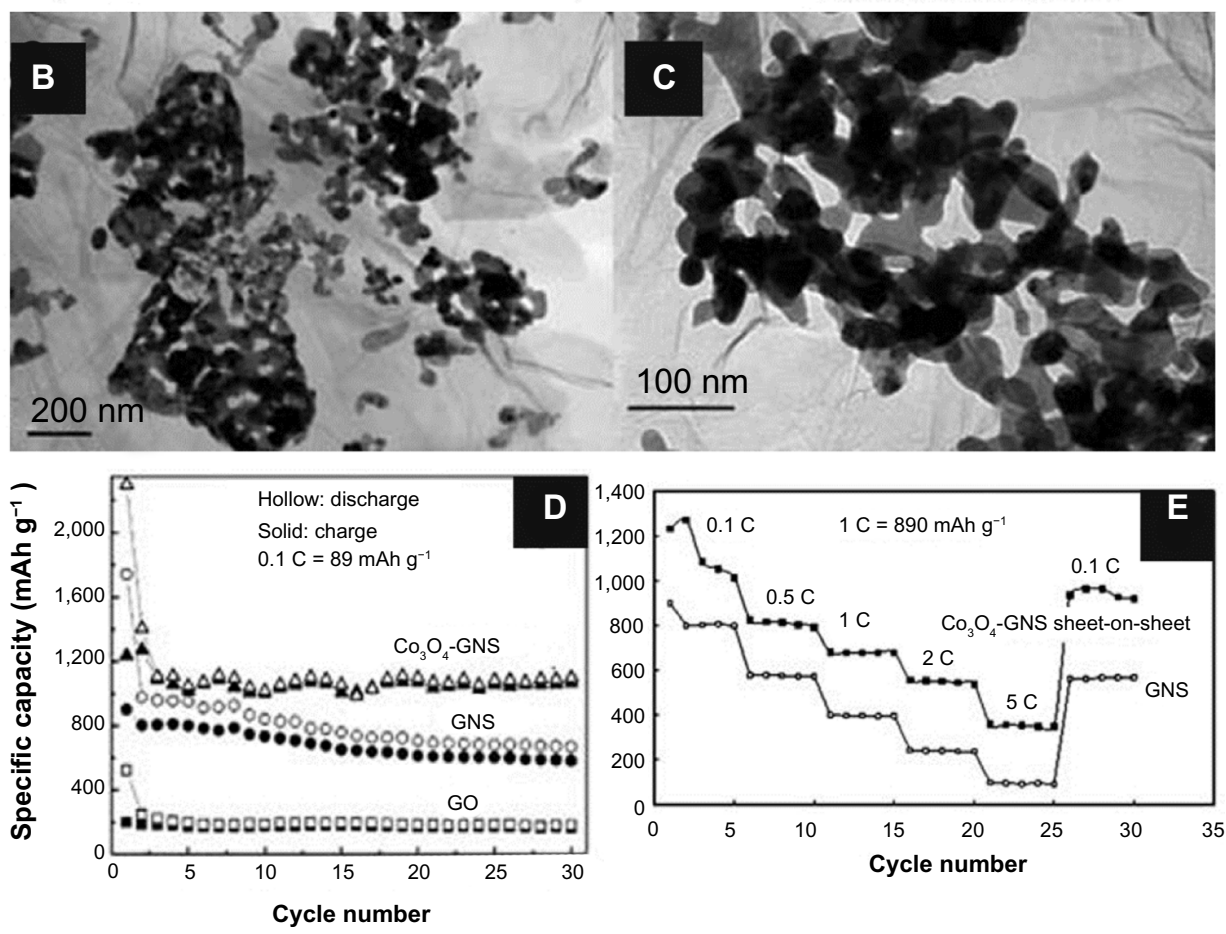

Figure 2 The $\mathrm{Co}_{3} \mathrm{O}_{4}$-GNS composite and its electrochemical properties.

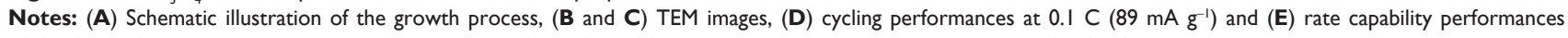
of $\mathrm{Co}_{3} \mathrm{O}_{4}$-GNS sheet-on-sheet composite. Reproduced from Chen SQ, Wang Y. Microwave-assisted synthesis of a $\mathrm{Co}_{3} \mathrm{O}_{4}$-graphene sheet-on-sheet nanocomposite as a superior anode material for Li-ion batteries. J Mater Chem. 2010;20:9735-9739, with permission from The Royal Society of Chemistry. ${ }^{77}$

Abbreviations: GNS, graphene nanosheet; GO, graphene oxide; TEM, transmission electron microscopy.

Noerochim et $\mathrm{al}^{91}$ and exhibits initial discharge capacity of $291 \mathrm{mAh} \mathrm{g}^{-1}$ at $100 \mathrm{~mA} \mathrm{~g}^{-1}$ and $172 \mathrm{mAh} \mathrm{g}^{-1}$ after 100 cycles. Moreover, 3D porous $\mathrm{MoO}_{2}$ /graphene microspheres were prepared in a microwave-assisted hydrothermal process. The obtained $\mathrm{MoO}_{2}$ /graphene composite exhibits excellent cycling stability of $1,300 \mathrm{mAh} \mathrm{g}^{-1}$ after 80 cycles at $0.1 \mathrm{C}$ and good rate capability of 913 and $390 \mathrm{mAh} \mathrm{g}^{-1}$ at 2 and $5 \mathrm{C}$, respectively. ${ }^{92}$ The $\mathrm{ZnO} @$ graphene composite ${ }^{93}$ was synthesized from $\mathrm{ZnO}$ nanoparticles via a microwave-assisted deposition on GO in a microwave oven. It exhibits improved electrochemical performance with a high capacity of $850 \mathrm{mAh} \mathrm{g}^{-1}$ at $0.1 \mathrm{C}$. There is a small capacity decay of $\sim 8 \%$ during 50 cycles of discharge and charge.

\section{GNS-supported tin/germanium/ silicon based anodes}

Tin, germanium and silicon are high-capacity elements for lithium storage, whose theoretical capacities values are 990, 

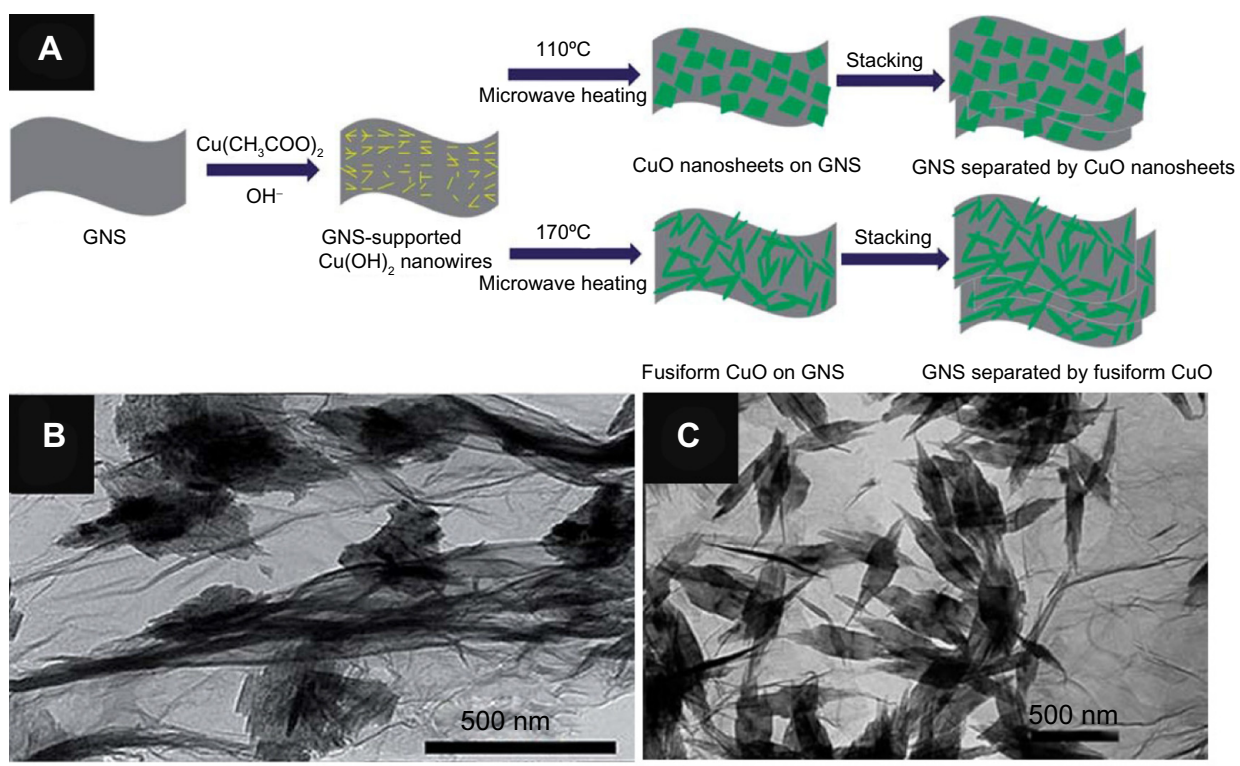

Fusiform $\mathrm{CuO}$ on GNS GNS separated by fusiform CuO
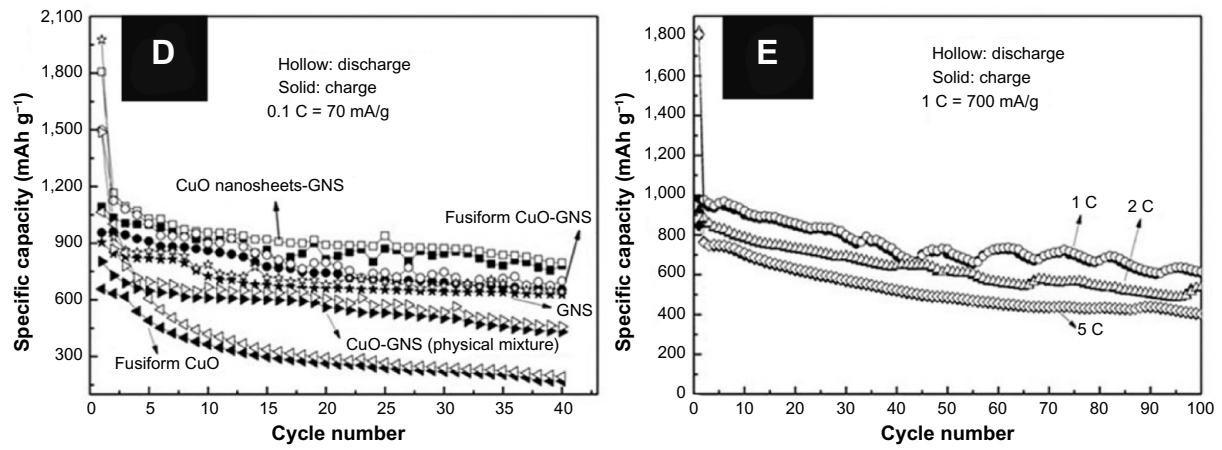

Figure 3 The CuO-GNS composites and their electrochemical properties.

Notes: (A) Schematic illustration of the growth process of CuO-GNS sheet-on-sheet and fusiform-on-sheet structures, (B) TEM image of the CuO-GNS sheet-on-sheet composite, (C) TEM image of the CuO-GNS fusiform-on-sheet composite, (D) cycling performances at 0.1 C $\left(70 \mathrm{~mA} \mathrm{~g}^{-1}\right)$ for various CuO-GNS composites, (E) rate capability performances of the CuO-GNS sheet-on-sheet composite. Reproduced from Lu LQ, Wang Y. Sheet-like and fusiform CuO nanostructures grown on graphene by rapid microwave heating for high Li-ion storage capacities. J Mater Chem. 201 I;21:17916-17921, with permission from The Royal Society of Chemistry. ${ }^{82}$

Abbreviations: GNS, graphene nanosheets; TEM, transmission electron microscopy.

1,600 , and 4,200 $\mathrm{mAh}^{-1}$, respectively. These theoretical values are calculated based on the lithium-ion reaction to form lithium alloys $\left(\mathrm{Li}_{4.4} \mathrm{Sn}, \mathrm{Li}_{4.4} \mathrm{Ge}\right.$, and $\left.\mathrm{Li}_{4.4} \mathrm{Si}\right)$. It is worth noting that these elements are often used as oxides such as $\mathrm{SnO}, \mathrm{SnO}_{2}, \mathrm{GeO}_{2}$, and $\mathrm{SiO}_{2}$. The lithium ion can reduce these oxides to $\mathrm{Sn}, \mathrm{Ge}$, and $\mathrm{Si}$ at an early stage, followed by a similar lithium alloy and de-alloy storage mechanism. The oxygen element in these oxides is usually believed to be inactive for lithium ion storage. As summarized in Table 2, among the reported GNS-supported lithium alloy anodes by microwaveassisted technology, $\mathrm{Sn}^{94-98}$ or $\mathrm{SnO}_{2}{ }^{99-106}$ usually tends to form a nanoparticle/nanocrystal morphology in the presence of GNS. GNS-supported Ge nanoparticle ${ }^{107}$ or thin film ${ }^{108}$ and GNSsupported Si nanoparticle ${ }^{109}$ or thin film ${ }^{110}$ was also synthesized by microwave irradiation or microwave plasma methods.

Figure 5A shows the schematic illustration of the preparation of graphene-supported Sn nanoparticles, which were synthesized via a single-mode microwave hydrothermal process in a microwave reactor, followed by hydrogen gas reduction..$^{95}$ Figure 5B and $\mathrm{C}$ show the obtained GNSsupported $\mathrm{Sn}$ nanoparticles. Interestingly, the size of $\mathrm{Sn}$ nanoparticles in the Sn-GNS composite is changed from 60-120 nm (Sn-GNS-1) to 10-20 nm (Sn-GNS-2) when the ratio of $\mathrm{Sn}$ and GNS is reduced from 1:1 to 1:4. When used as the anode for LIBs, the Sn-GNS-1 and Sn-GNS-2 composites deliver reversible charge capacities of 1,206 and 1,407 $\mathrm{mAh} \mathrm{g}^{-1}$, respectively, with the corresponding Coulombic efficiencies of $67.9 \%$ and $65.9 \%$. As shown in the cycling performance curves of Figure 5D, the Sn-GNS-1 and Sn-GNS-2 electrodes deliver specific capacities of 772 and $1,100 \mathrm{mAh} \mathrm{g}^{-1}$, respectively, after 30 cycles at $0.1 \mathrm{C}$, which are both higher than that for bare GNS (582 $\left.\mathrm{mAh} \mathrm{g}^{-1}\right)$ after the same cycle number. The enhanced high-rate properties are also observed for Sn-GNS-2, which exhibits specific 

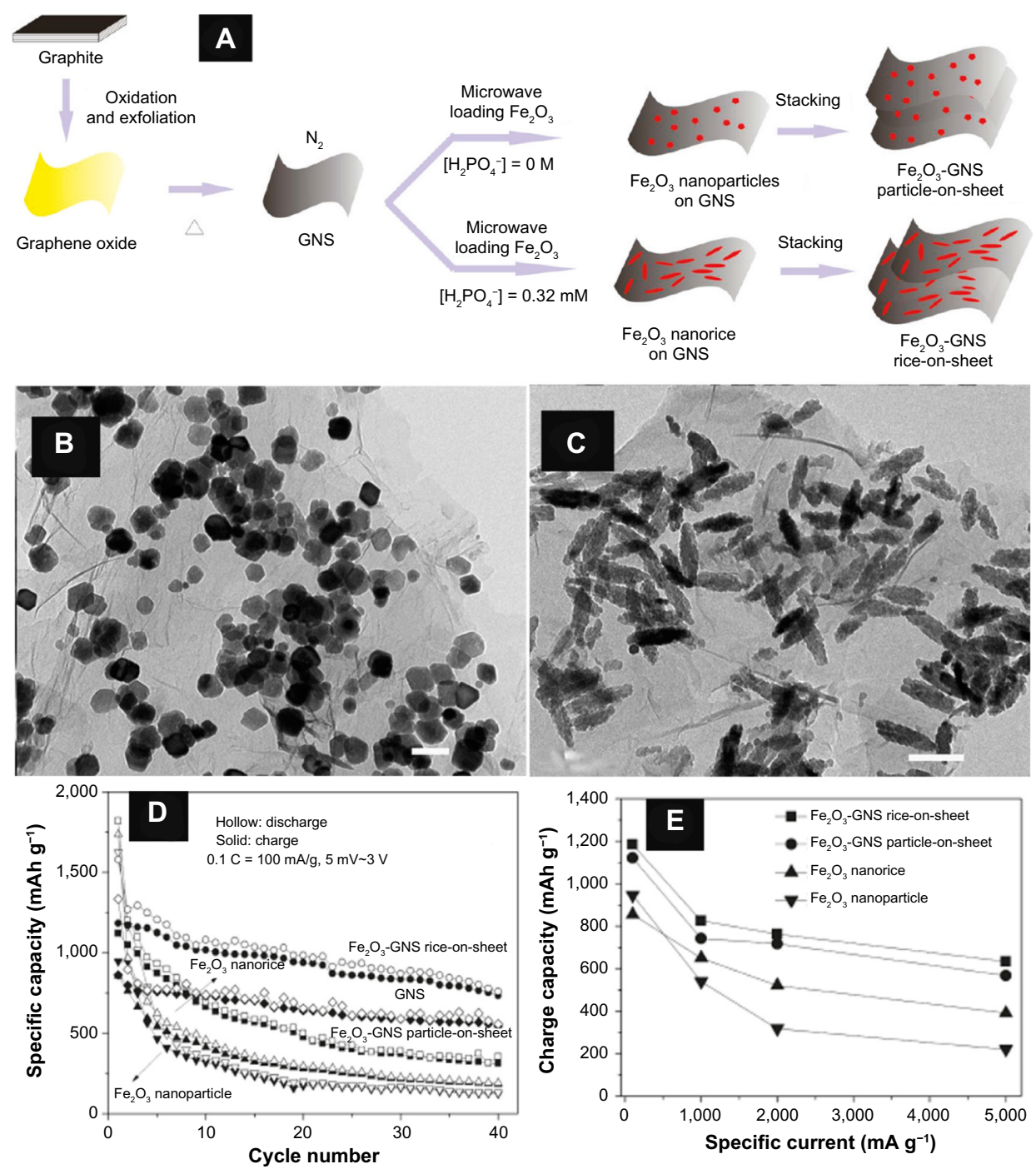

Figure 4 The $\mathrm{Fe}_{2} \mathrm{O}_{3}$-GNS composites and their electrochemical properties.

Notes: (A) Schematic illustration of the growth process of $\mathrm{Fe}_{2} \mathrm{O}_{3}$-GNS particle-on-sheet and rice-on-sheet composites. TEM images of (B) Fe $\mathrm{O}_{3}$-GNS particle-on-sheet and (C) $\mathrm{Fe}_{2} \mathrm{O}_{3}$-GNS rice-on-sheet composite. Electrochemical performances of $\mathrm{Fe}_{2} \mathrm{O}_{3}$-GNS composites: (D) cycling performances at $0.1 \mathrm{C}$ (I00 mA g $\mathrm{g}^{-1}$ ) and (E) rate capability. Reprinted with permission from Zou YQ, Kan J, Wang Y. $\mathrm{Fe}_{2} \mathrm{O}_{3}$-graphene rice-on-sheet nanocomposite for high and fast lithium ion storage. J Phys Chem C. 20II; II5: 20747-20753. Copyright (c) 2011. American Chemical Society. ${ }^{89}$

Abbreviations: GNS, graphene nanosheets; TEM, transmission electron microscopy.

discharge capacities of $1,247,1,106,946$, and $876 \mathrm{mAh} \mathrm{g}^{-1}$ at current densities of $0.5,1,2$, and 5 C. Moreover, a new strategy for the growth of self-assembled Sn@CNT on vertically aligned graphene (VAGN) was suggested by the microwave plasma irradiation method in MPCVD system. ${ }^{94} \mathrm{SnO}_{2}$ is reduced to Sn on VAGN and subsequently encapsulated in the catalyzed carbon nanotubes (CNTs). In the Sn@CNT product, pear-like $\mathrm{Sn}$ core with a diameter of about $30 \mathrm{~nm}$ and a length of $40-50 \mathrm{~nm}$ is encapsulated inside a cylindrical CNT with a length less than $100 \mathrm{~nm}$. The whole Sn@CNT structure is anchored on the surface of GNS. Such a composite exhibits a high reversible capacity of $1,026 \mathrm{mAh} \mathrm{g}^{-1}$ at $0.25 \mathrm{C}$, and a capacity of $140 \mathrm{mAh} \mathrm{g}^{-1}$ is retained in a short discharge time of 12 seconds. A Sn@graphene on the
VAGN structure ${ }^{97}$ was also reported by the same authors as above, which exhibits a reversible capacity of $1,005 \mathrm{mAh} \mathrm{g}^{-1}$ at $0.25 \mathrm{C}$ even after 120 cycles. Meanwhile, there are several other reports on GNS-supported $\mathrm{SnO}_{2}$ particles ${ }^{99-106}$ prepared by microwave-assisted method. Excellent electrochemical properties (a stable capacity of $\sim 890 \mathrm{mAh} \mathrm{g}^{-1}$ without noticeable fading up to 80 cycles at $500 \mathrm{~mA} \mathrm{~g}^{-1}$ ) were observed for the GNS-SnO ${ }_{2}$ nanocomposite, which was synthesized by a microwave-assisted hydrothermal process. ${ }^{101}$

A unique sandwich-structured C/Ge/graphene composite ${ }^{107}$ was synthesized by a microwave-solvothermal process as shown in Figure 6A. A carbon coating layer is introduced on the surface of the graphene/germanium oxide composite precursor, followed by a reduction treatment. The composite consists of 
Table 2 Summary on the morphologies and electrochemical performances of graphene-supported Sn/Ge/Si-based anodes

\begin{tabular}{|c|c|c|c|}
\hline Composites & Morphologies & Electrochemical performances & Reference \\
\hline Sn@CNTs-GNS & Nanoparticle-on-sheet & 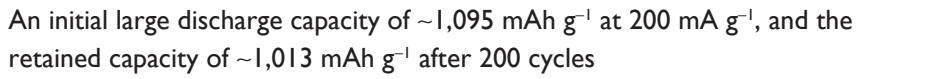 & 94 \\
\hline Sn/GNS & Nanoparticle-on-sheet & $\begin{array}{l}\text { Charge capacities of I,206 and I,407 } \mathrm{mAh}^{-1} \text { with retained capacities of } 772 \text { and } \\
\mathrm{I}, 100 \mathrm{mAh} \mathrm{g}^{-1} \text { after } 30 \text { cycles at } 0.1 \mathrm{C} \text { for Sn-GNS-I and Sn-GNS-2, respectively }\end{array}$ & 95 \\
\hline C-Sn/GNS & Nanoparticle-on-sheet & $\begin{array}{l}\text { A stable capacity of } \sim 600 \mathrm{mAh} \mathrm{g}^{-1} \text { at } 100 \mathrm{~mA} \mathrm{~g}^{-1} \text { with a higher capacity retention } \\
\text { of } 87 \% \text { after } 20 \text { cycles }\end{array}$ & 96 \\
\hline Sn/GNS & Nanoparticle-on-sheet & 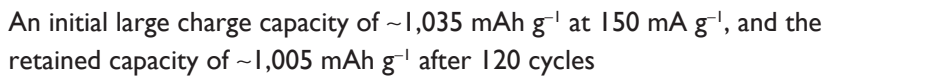 & 97 \\
\hline Sn/GNS & Nanoparticle-on-sheet & $\begin{array}{l}\text { Discharge capacities of I,300 and } 730 \mathrm{mAh} \mathrm{g}^{-1} \text { after } 40 \text { cycles for as deposited } \\
\text { and annealed Sn-GNS, respectively }\end{array}$ & 98 \\
\hline $\mathrm{SnO}_{2} / \mathrm{GNS}$ & Nanoparticle-on-sheet & Capacities between 400 and $500 \mathrm{mAh} \mathrm{g^{-1 }}$ after 80 cycles & 99 \\
\hline $\mathrm{SnO}_{2} / \mathrm{GNS}$ & Nanoparticle-on-sheet & $\begin{array}{l}\text { Retained capacities of } 590 \text { and } 504 \mathrm{mAh} \mathrm{g}^{-1} \text { after } 200 \text { cycles for } \mathrm{SnO}_{2} \text {-GNSI and } \\
\mathrm{SnO}_{2} \text {-GNS2, respectively }\end{array}$ & 100 \\
\hline $\mathrm{SnO}_{2} / \mathrm{GNS}$ & Nanoparticle-on-sheet & $\begin{array}{l}\text { A stable capacity of about } 890 \mathrm{mAh} \mathrm{g}^{-1} \text { without noticeable fading up to } 80 \text { cycles } \\
\text { at } 500 \mathrm{~mA} \mathrm{~g}^{-1}\end{array}$ & 101 \\
\hline $\mathrm{SnO}_{2} / \mathrm{GNS}$ & Nanocrystal-on-sheet & 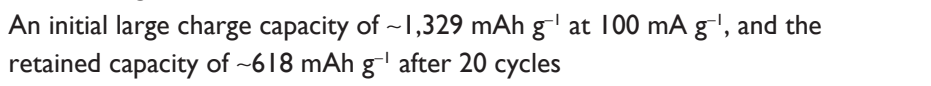 & 102 \\
\hline $\mathrm{SnO}_{2}-\mathrm{RGO}-\mathrm{CNT}$ & Nanoparticle-on-sheet & $\begin{array}{l}\text { A reversible capacity of the composite retains } 502 \mathrm{mAh} \mathrm{g}^{-1} \text { after } 50 \text { cycles at } \\
100 \mathrm{~mA} \mathrm{~g}^{-1} \text {, and a capacity of } 344 \mathrm{mAh} \mathrm{g}^{-1} \text { at } 1,000 \mathrm{~mA} \mathrm{~g}^{-1}\end{array}$ & 103 \\
\hline $\mathrm{SnO}_{2} / \mathrm{GNS}$ & Nanoparticle-on-sheet & 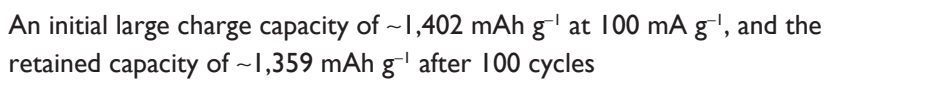 & 104 \\
\hline $\mathrm{SnO}_{2} / \mathrm{GNS}$ & Nanoparticle-on-sheet & A reversible capacity of $635 \mathrm{mAh} \mathrm{g}^{-1}$ retains after 100 cycles at $60 \mathrm{~mA} \mathrm{~g}^{-1}$ & 105 \\
\hline $\mathrm{SnO}_{2} / \mathrm{GNS}$ & Nanoparticle-on-sheet & $\begin{array}{l}\text { A stable specific capacity of about } 430 \mathrm{mAh} \mathrm{g}^{-1} \text { retained after more than } \\
\text { I } 40 \text { cycles at } 500 \mathrm{~mA} \mathrm{~g}^{-1} \text { with a Coulombic efficiency close to } 100 \%\end{array}$ & 106 \\
\hline C-Ge-GNS & Nanoparticle-on-sheet & A reversible capacity of $993 \mathrm{mAh} \mathrm{g}^{-1}$ retains after 160 cycles at $0.4 \mathrm{C}$ & 107 \\
\hline Ge/GNS & 3D network & $\begin{array}{l}\text { A reversible capacity of I, } 140 \mathrm{mAh} \mathrm{g}^{-1} \text { at } 0.33 \mathrm{C} \text { over } 100 \text { cycles and } 835 \mathrm{mAh} \mathrm{g}^{-1} \\
\text { at } 8 \mathrm{C} \text { after } 60 \text { cycles }\end{array}$ & 108 \\
\hline $\mathrm{Si} / \mathrm{GNS}$ & Nanoparticle-on-sheet & $\begin{array}{l}\text { Discharge capacity retention of about } 800 \mathrm{mAh} \mathrm{g}^{-1} \text { after } 100 \text { cycles at a current } \\
\text { of } 500 \mathrm{~mA} \mathrm{~g}^{-1}\end{array}$ & 109 \\
\hline Si/GNS & Film-on-sheet & $\begin{array}{l}\text { A capacity of } 1,314 \mathrm{mAh} \mathrm{g}^{-1} \text { after } 500 \text { cycles with capacity retention of } 84 \% \\
\text { relative to the maximum capacity of } 1,560 \mathrm{mAh} \mathrm{g}^{-1} \text { in the } 50 \text { th cycle }\end{array}$ & 110 \\
\hline Ag/GNS & Nanoparticle-on-sheet & $\begin{array}{l}\text { An initial large charge capacity of } \sim 780 \mathrm{mAh} \mathrm{g}^{-1} \text { at } 0.1 \mathrm{C} \text {, and the retained } \\
\text { capacity of } \sim 714 \mathrm{mAh} \mathrm{g}^{-1} \text { after } 50 \text { cycles }\end{array}$ & 111 \\
\hline $\mathrm{Ag} / \mathrm{GNS}$ & Nanorod-on-sheet & $\begin{array}{l}\text { A high reversible capacity of } 1,015 \mathrm{mAh} \mathrm{g}^{-1} \text { at } 0.1 \mathrm{C} \text { with a high capacity } \\
\text { retention rate of } 64.1 \% \text { at } 5 \mathrm{C}\end{array}$ & 112 \\
\hline
\end{tabular}

Abbreviations: CNTs, carbon nanotubes; GNS, graphene nanosheets; RGO, reduced graphene oxide.

metallic germanium nanoparticles ( $20-30 \mathrm{~nm}$ in size) between graphene sheets and carbon layers (Figure 6B and C). The $\mathrm{C} / \mathrm{Ge} /$ graphene composite shows better cycling performances (a capacity of $993 \mathrm{mAh} \mathrm{g}^{-1}$ after 160 cycles, corresponding to $86.4 \%$ of the capacity at the second cycle) and rate capability (discharge capacity of $1,008 \mathrm{mAh} \mathrm{g}^{-1}$ after 30 cycles at $5 \mathrm{C}$ ) than the $\mathrm{Ge} / \mathrm{C}$ and $\mathrm{Ge} /$ graphene composites.

3D graphene scaffold-supported Si thin film composite was prepared by Wang et al. ${ }^{110}$ As shown in Figure 7A, a 3D graphene scaffold is first synthesized using a MPCVD approach, and $\mathrm{Si}$ is then deposited on the graphene scaffold using radio frequency sputtering. The obtained $\mathrm{Si}$ grains $(0.3-0.5 \mu \mathrm{m})$ are deposited on the surface of $3 \mathrm{D}$ graphene (Figure 7B). Figure 7C shows that these $\mathrm{Si}$ grains are composed of numerous Si nanoparticles (several nanometers in size). When used for LIBs, such 3D graphene scaffold-supported Si electrode exhibits an outstanding cycling stability. A capacity of $1,314 \mathrm{mAh} \mathrm{g}^{-1}$ can be observed after 500 cycles with capacity retention of $84 \%$ relative to the maximum capacity of $1,560 \mathrm{mAh} \mathrm{g}^{-1}$ in the 50 th cycle. The composite also exhibits good high-rate cycling performances and a large capacity of $1,083 \mathrm{mAh} \mathrm{g}^{-1}$ is still retained after 1,200 cycles at a large current of $2.39 \mathrm{~A} \mathrm{~g}^{-1}$.

Based on the similar lithium alloy and de-alloy storage mechanism to $\mathrm{Sn}, \mathrm{Ge}$, and $\mathrm{Si}, \mathrm{Ag}$ and $\mathrm{Ag}$-based composites were also explored as the anodes for LIBs. ${ }^{111,112}$ It is found in the literature that only GNS-supported Ag nanoparticle ${ }^{111}$ / nanorod ${ }^{112}$ composites were synthesized by microwaveassisted methods and their electrochemical properties are presented in Table 2. The Ag nanorod on GNS ${ }^{112}$ is obtained 

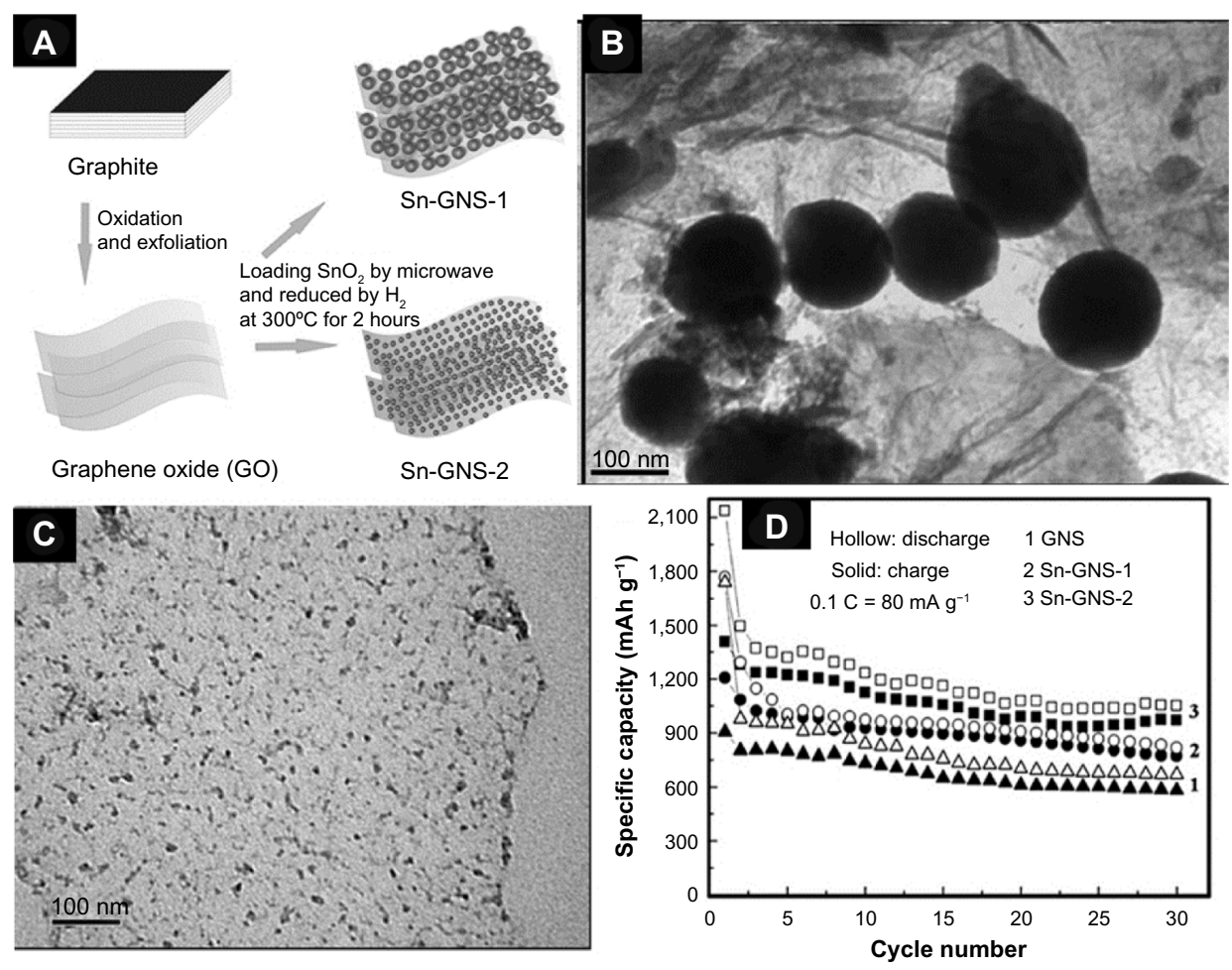

Figure 5 The Sn-GNS composites and their electrochemical properties.

Notes: (A) Schematic illustration for the preparation process of Sn-GNS nanocomposites, (B) TEM images of Sn-GNS-I (the weight ratios of Sn and GNS being I:I), (C) TEM images of Sn-GNS-2 (the weight ratios of Sn and GNS being I:4), (D) cycling performances of Sn-GNS composites at 80 mA g-1. Reprinted from J Power Sources, 216, Chen SQ, Wang Y, Ahn H, Wang GX, Microwave hydrothermal synthesis of high performance tin-graphene nanocomposites for lithium ion batteries, 22-27, Copyright (C) 2012 with permission from Elsevier. ${ }^{95}$

Abbreviations: GNS, graphene nanosheets; TEM, transmission electron microscopy.

by reducing Ag-GO hybrid. The Ag-GO precursor is prepared by two steps: Ag nanorods are first synthesized in a microwave solvothermal process in a household microwave oven and then mixed with GO prepared from Hummer's method. The Ag-GNS nanorod-on-sheet composite shows a high reversible capacity of $1,015 \mathrm{mAh} \mathrm{g}^{-1}$ at $0.1 \mathrm{C}$ with a high capacity retention rate of $64.1 \%$ at $5 \mathrm{C}$. By a similar microwave solvothermal process, GNS-Ag nanoparticle composite ${ }^{111}$ was synthesized from natural graphite and silver salt, and it exhibits an initial charge capacity of $780 \mathrm{mAh} \mathrm{g}^{-1}$, which decreases to $714 \mathrm{mAh} \mathrm{g}^{-1}$ after 50 cycles.

\section{GNS-supported metal sulfide anodes}

Metal sulfides are also promising high-capacity anode materials for LIBs. The active element for lithium ions can be either metal (eg, $\mathrm{Sn}$ of $\mathrm{SnS}_{2}$ ) or sulfur (eg, S of CoS and $\mathrm{NiS}$ ). Metal and sulfur are also suggested to be both active for $\mathrm{In}_{2} \mathrm{~S}_{3}$ materials, although most studies still believe the active element is only sulfur. The lithium ion storage mechanism of tin sulfide is similar to tin oxides, in which sulfide and oxygen are both inactive and lithium can reversibly react with tin to form $\mathrm{Li}_{\mathrm{x}} \mathrm{Sn}$ alloys (the maximum $\mathrm{x}$ value is 4.4 ). The storage mechanism of active sulfur element is based on the reversible formation and decomposition of lithium sulfide.

There are few reports on the GNS-supported metal sulfide composites with microwave-assisted syntheses: GNSsupported $\mathrm{SnS}_{2}$ nanosheets, ${ }^{113} \mathrm{SnS}_{2}$ nanoparticles ${ }^{69} \mathrm{In}_{2} \mathrm{~S}_{3}$ particles and $\operatorname{In}_{2} S_{3}$ flowers ${ }^{114}$ composites were reported by Chen et al, Zou and Wang, and Gu and Wang, respectively. Their morphologies and lithium-storage properties are summarized in Table 3. A porous $3 \mathrm{D} \mathrm{SnS}_{2}$-reduced graphene oxide (RGO) sheet-on-sheet nanostructure was synthesized by a single-mode microwave solvothermal method at $180^{\circ} \mathrm{C}$ for 20 minutes in which $\mathrm{SnS}_{2}$ nanosheets are distributed uniformly on the RGO surface. ${ }^{113}$ If the amount of the starting GO is increased, the obtained $\mathrm{SnS}_{2}$ products are only nanoparticles. ${ }^{69}$ This is ascribed to the presence of a large amount of surface functionalities (mainly oxygen-containing groups) of GO, which can significantly affect the nucleation process of $\mathrm{SnS}_{2}$. As shown in Figure 8, large reversible capacities are observed from 1,077 to $896 \mathrm{mAh} \mathrm{g}^{-1}$ at $0.1 \mathrm{C}$ and 934 to $657 \mathrm{mAh} \mathrm{g}^{-1}$ at $1 \mathrm{C}$ in 40 cycles for the $\mathrm{SnS}_{2}-\mathrm{RGO}$ sheet-on-sheet composite. Compared with bare graphene and pristine $\mathrm{SnS}_{2}$ nanoflowers, such a sheet-on-sheet composite achieves better electrochemical performances, which is attributed to the synergetic effect 

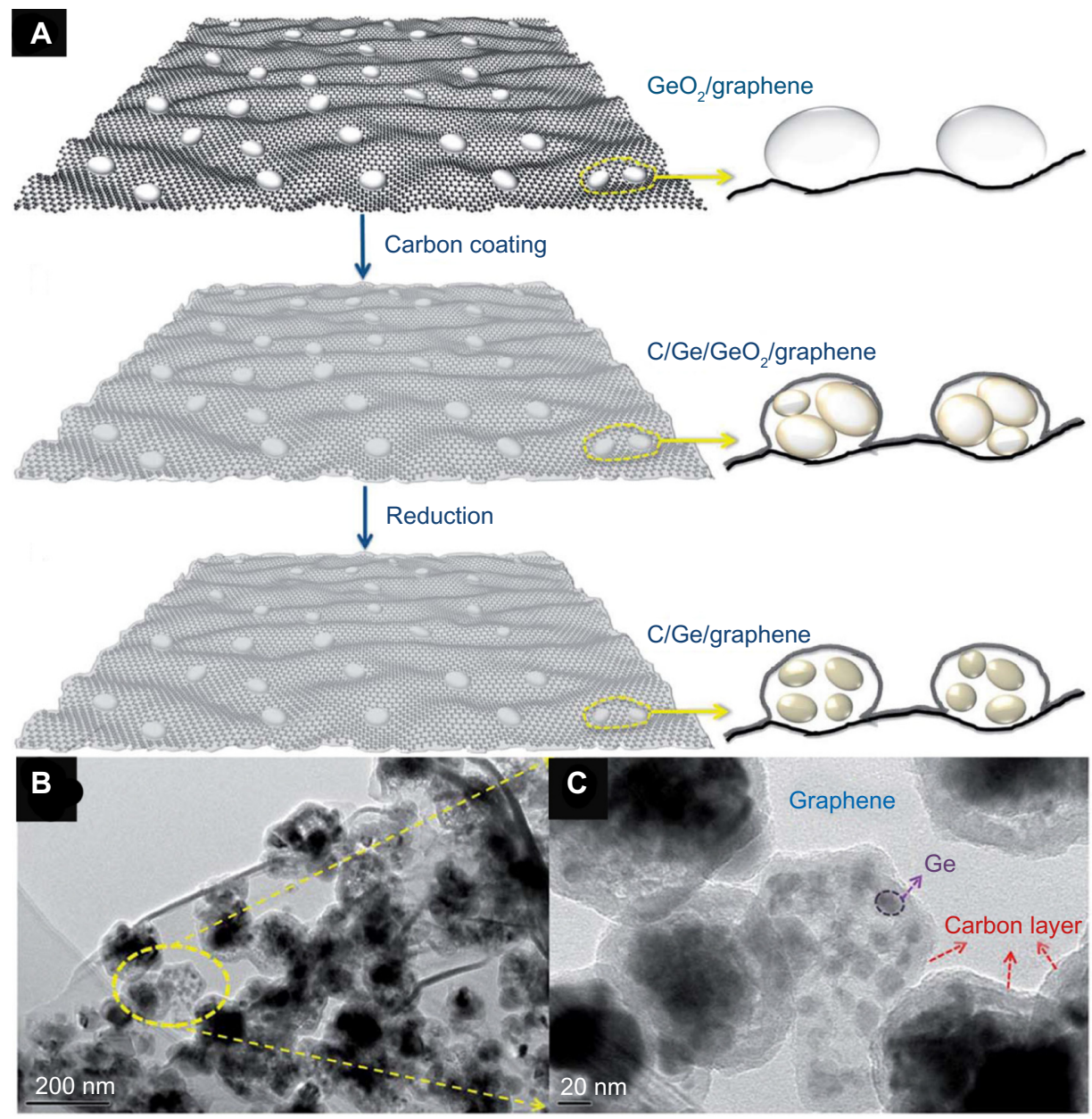

Figure 6 The $\mathrm{C} / \mathrm{Ge} / \mathrm{graphene}$ composite.

Notes: (A) Schematic illustration of the C/Ge/graphene composite, (B and C) TEM images of C/Ge/graphene composite at different magnifications. Reproduced from Li D, Seng KH, Shi DQ, Chen ZX, Liu HK, Guo ZP. A unique sandwich-structured C/Ge/graphene nanocomposite as an anode material for high power lithium ion batteries. J Mater Chem A. 2013;1:141 15-14121 with permission of The Royal Society of Chemistry.107

Abbreviation: TEM, transmission electron microscopy.
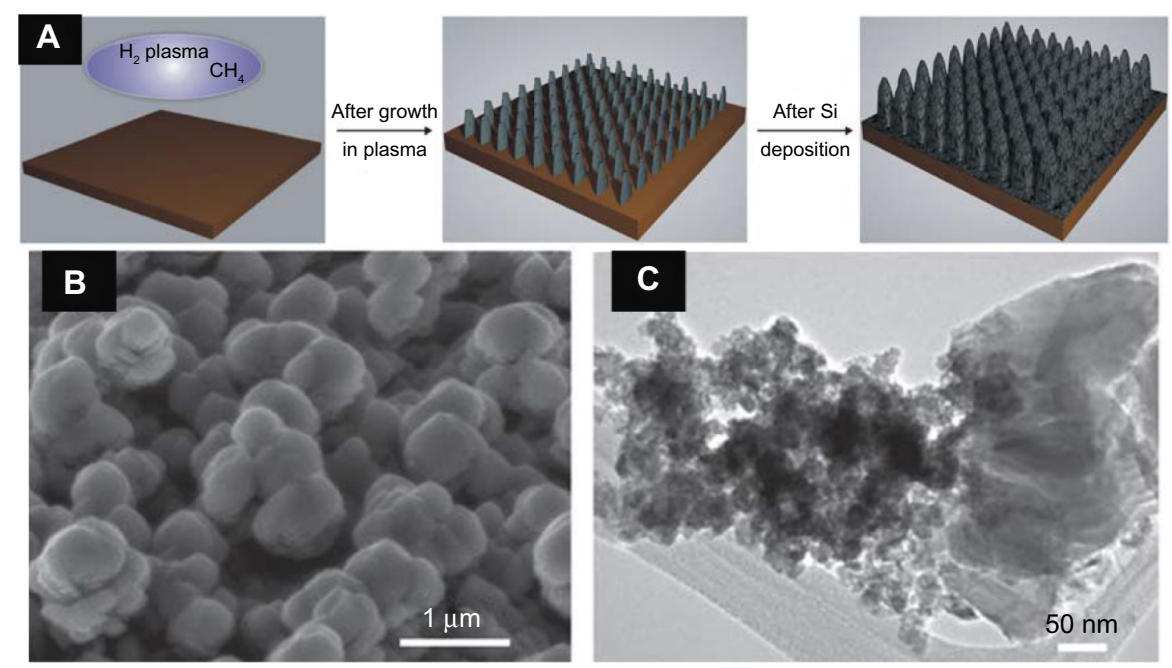

Figure 7 The graphene supported Si composite.

Notes: (A) Schematic illumination of the growth process of the 3D graphene scaffold supported Si electrode (GSSSE). The as-synthesized GSSSE: (B) SEM image and (C) TEM image. Reproduced from Wang CD, Chui YS, Ma RG, et al. A three-dimensional graphene scaffold supported thin film silicon anode for lithium-ion batteries. J Mater Chem A. 2013;1:10092-10098 with permission of The Royal Society of Chemistry. ${ }^{110}$

Abbreviations: SEM, scanning electron microscopy; TEM, transmission electron microscopy. 
Table 3 Summary on the morphologies and electrochemical performances of graphene-supported metal sulfides and lithium titaniumbased anodes

\begin{tabular}{|c|c|c|c|}
\hline Composites & Morphologies & Electrochemical performances & Reference \\
\hline $\mathrm{SnS}_{2} / \mathrm{GNS}$ & Sheet-on-sheet & $\begin{array}{l}\text { Large reversible capacities of } 1,077-896 \mathrm{mAh} \mathrm{g}^{-1} \text { at } 0.1 \mathrm{C} \text { and } 934-657 \mathrm{mAh} \mathrm{g}^{-1} \text { at } \\
\text { I C in } 40 \text { cycles }\end{array}$ & 113 \\
\hline $\ln _{2} S_{3} / G N S$ & Flower-on-sheet & A reversible capacity of the composite retains $657 \mathrm{mAh} \mathrm{g}^{-1}$ after 40 cycles at $70 \mathrm{~mA} \mathrm{~g}^{-1}$ & 114 \\
\hline $\ln _{2} S_{3} / G N S$ & Particle-on-sheet & A reversible capacity of the composite retains $614 \mathrm{mAh} \mathrm{g}^{-1}$ after 40 cycles at $70 \mathrm{~mA} \mathrm{~g}^{-1}$ & 114 \\
\hline $\mathrm{Li}_{4} \mathrm{Ti}_{5} \mathrm{O}_{12} / \mathrm{GNS}$ & Microsphere-on-sheet & $\begin{array}{l}\text { Capacities of I68, I6I, I53, I47, I43, I32, II9, and } 106 \mathrm{mAh} \mathrm{g}^{-1} \text { at } 0.2,0.4,1,2,4,10,20 \text {, } \\
\text { and } 40 \mathrm{C} \text {, respectively }\end{array}$ & 115 \\
\hline $\mathrm{Li}_{4} \mathrm{Ti}_{5} \mathrm{O}_{12} / \mathrm{RGO}$ & Nanoparticle-on-sheet & A reversible capacity of $168 \mathrm{mAh} \mathrm{g}^{-1}$ at I C with a high capacity retention rate of $59 \%$ at $50 \mathrm{C}$ & 116 \\
\hline $\mathrm{Li}_{4} \mathrm{Ti}_{5} \mathrm{O}_{12} / \mathrm{RGO}$ & Nanoplatelet-on-sheet & A discharge capacity of 154,128 , and $101 \mathrm{mAh} \mathrm{g}^{-1}$ at I, 50 , and $100 \mathrm{C}$, respectively & 117 \\
\hline $\mathrm{TiO}_{2} / \mathrm{RGO}$ & Microspheres-on-sheet & A large discharge capacity of $156 \mathrm{mAh} \mathrm{g}^{-1}$ at $5 \mathrm{C}$, and $84 \mathrm{mAh} \mathrm{g}^{-1}$ retained at $60 \mathrm{C}$ & 118 \\
\hline
\end{tabular}

Abbreviations: GNS, graphene nanosheets; RGO, reduced graphene oxide.

for highly reversible lithium-ion storage that resulted from the closely contacted sheet-on-sheet morphology. These electrochemical properties of the sheet-on-sheet composite are also superior to previous $\mathrm{SnS}_{2}$-GNS particle-on-sheet composite ${ }^{69}$ in which an initial charge capacity of $858 \mathrm{mAh} \mathrm{g}^{-1}$ is decreased to $652 \mathrm{mAh} \mathrm{g}^{-1}$ after 40 cycles.

GNS-supported $\operatorname{In}_{2} \mathrm{~S}_{3}$ nanoparticle and interconnected nanoflower composites were synthesized by the similar single-mode microwave hydrothermal method at $140^{\circ} \mathrm{C}$ under a pressure of 5.5 bars for 20 minutes ${ }^{114}$ Black powders of $\mathrm{In}_{2} \mathrm{~S}_{3}$-graphene particle-on-sheet composite are obtained instead of the tawny powders of $\operatorname{In}_{2} \mathrm{~S}_{3}$-graphene flower-onsheet when the dosage of graphene is increased. As indicated by Figure $9, \operatorname{In}_{2} \mathrm{~S}_{3}$ nanoparticles and nanoflowers are uniformly dispersed on GNS, forming sandwiched particle-on-sheet and unprecedented flower-on-sheet nanostructures. Compared with GNS and pristine $\mathrm{In}_{2} \mathrm{~S}_{3}$, the GNS-supported $\mathrm{In}_{2} \mathrm{~S}_{3}$ composites show extraordinary large reversible capacities and good cycling performances. Reversible initial capacities of $1,249,913,782$, and $690 \mathrm{mAh} \mathrm{g}^{-1}$ are observed at currents of $70,700,1,400,3,500 \mathrm{~mA} \mathrm{~g}^{-1}$, respectively, for the flower-onsheet composite, while the particle-on-sheet composite shows slightly lower reversible capacities but more stable cycling performances at both small and high currents.

\section{Graphene-supported lithium titanium oxide based anodes}

Lithium-titanium-oxide-based materials are important highrate anodes for lithium ion batteries, which are based on the lithium insertion mechanism of lithium storage. Although their theoretical capacities are even lower than graphite anodes, they exhibit very good cyclabilities because there is only a small volume change during the process of lithium insertion and extraction. A summary of morphologies and electrochemical performances of graphene-supported lithium-titanium- oxide-based anodes is given in Table 3. For example, $\mathrm{Li}_{4} \mathrm{Ti}_{5} \mathrm{O}_{12}$ has been suggested as a zero-strain material with almost no structure change during cycling. ${ }^{115,116}$ The microwavehydrothermal method was reported to prepare $\mathrm{Li}_{4} \mathrm{Ti}_{5} \mathrm{O}_{12}$ microspheres composed of nanoflakes wrapped in GNS. ${ }^{115}$ The obtained structure can avoid the restacking of GNS and offer rapid lithium diffusion; therefore, the composite exhibits highly desirable Li-ion storage properties in terms of a large capacity (168 $\mathrm{mAh} \mathrm{g}^{-1}$ at $\left.0.2 \mathrm{C}\right)$ approaching the theoretical value, stable cycling performance, and excellent rate capability. The $\mathrm{Li}_{4} \mathrm{Ti}_{5} \mathrm{O}_{12} /$ graphene composite was also prepared by the lithiation of the alkali titanate with the assistance of microwave. ${ }^{116}$ The composite exhibits a reversible capacity of $168 \mathrm{mAh} \mathrm{g}^{-1}$ at a current rate of $1 \mathrm{C}$ with a high capacity retention rate of $59 \%$ at a very large current rate of $50 \mathrm{C}$. Kim et al also reported $\mathrm{Li}_{4} \mathrm{Ti}_{5} \mathrm{O}_{12}$ nanoplatelet/RGO hybrid, ${ }^{117}$ which was obtained from $\mathrm{TiO}_{2} / \mathrm{RGO}$ nano-hybrid in $\mathrm{LiOH}$ aqueous solution via a microwave hydrothermal process. The composite can deliver a discharge capacity of 154,128 , and $101 \mathrm{mAh} \mathrm{g}^{-1}$ (based on $\mathrm{Li}_{4} \mathrm{Ti}_{5} \mathrm{O}_{12}$ ) at 1,50 , and $100 \mathrm{C}$, respectively. As reported by Yan et al, a facile microwave solvothermal process was developed to prepare an anatase $\mathrm{TiO}_{2}$ anode material that maintains multiple properties including high surface area, high crystallinity, uniform mesoporous structure, perfect microspheres, and uniform particle size. ${ }^{18}$ Using this fine anatase $\mathrm{TiO}_{2}$ product, $\mathrm{a} \mathrm{TiO}_{2} / \mathrm{RGO}$ hybrid material ${ }^{118}$ was prepared under UV-light irradiation. The incorporation of RGO improves the electrochemical kinetics of the $\mathrm{TiO}_{2}$ microspheres (Figure 10), which results in superior electrochemical performance in terms of specific capacity, rate capability, and cycle stability. The lithium storage mechanism of the anatase $\mathrm{TiO}_{2}$ is also a lithium insertion mechanism. A reversible lithium insertion and extraction reaction between $\mathrm{TiO}_{2}$ and $\mathrm{Li}_{0.5} \mathrm{TiO}_{2}$ leads to a theoretical capacity of $\sim 168 \mathrm{mAh} \mathrm{g}^{-1}$. The composite also shows a large discharge capacity of $156 \mathrm{mAh} \mathrm{g}^{-1}$ at a large 

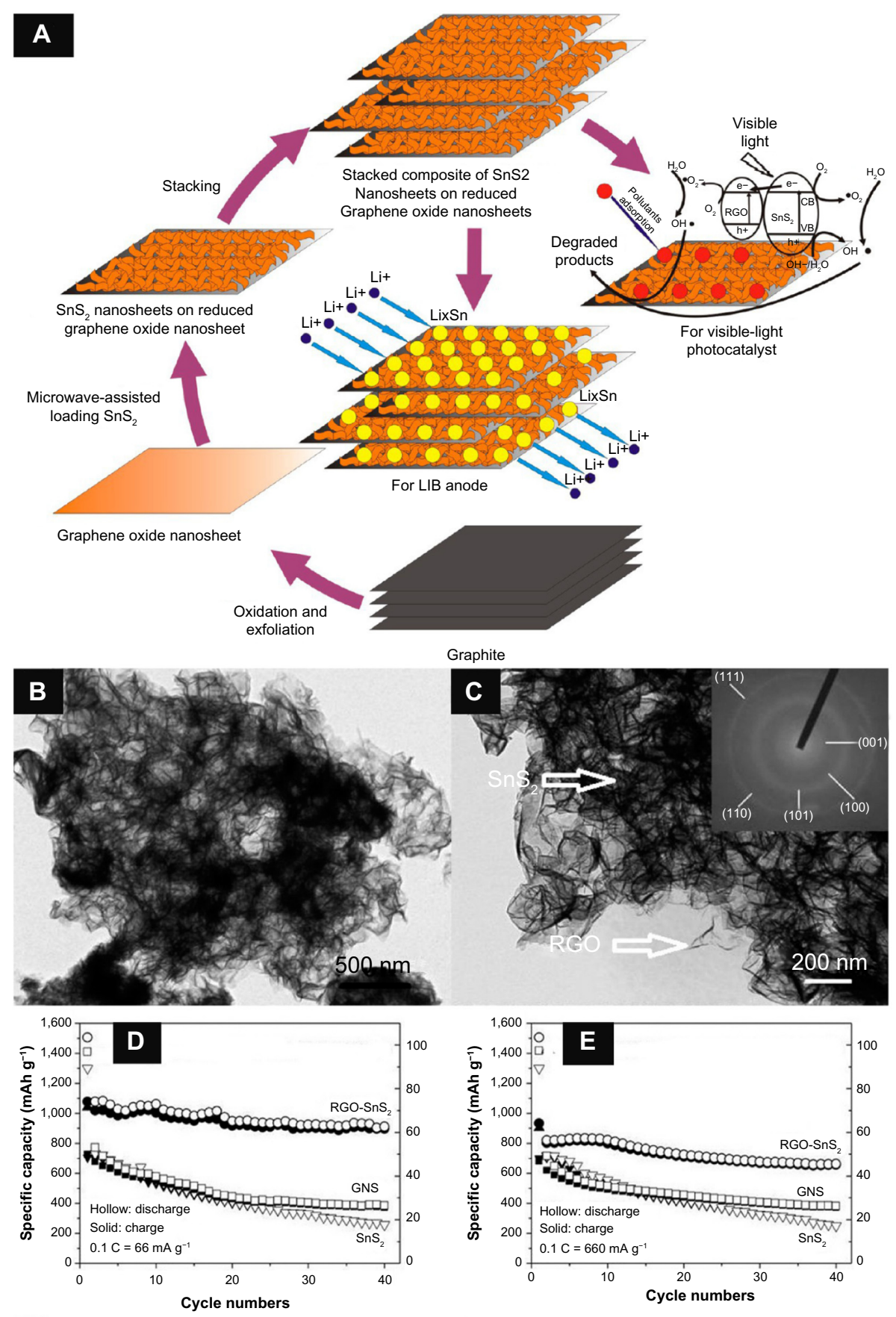

Figure 8 The SnS - -GNS composite and its electrochemical properties.

Notes: (A) Schematic illustration of the growth process and applications of $\mathrm{SnS}_{2}-\mathrm{RGO}$ sheet-on-sheet nanostructure, (B and C) TEM images of SnS - RGO sheet-onsheet composite. The inset of (C) showing the selected area electronic diffraction (SAED) pattern of polycrystalline SnS. Cycling performances of the products: (D) 0.1 C $\left(66 \mathrm{~mA} \mathrm{~g}^{-1}\right)$ and $(E)$ I C. Reprinted with permission from Chen P, Su Y, Liu H, Wang Y. Interconnected tin disulfide nanosheets grown on graphene for Li-ion storage and

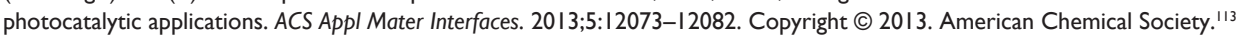

Abbreviations: LIB, lithium ion battery; RGO, reduced graphene oxide; TEM, transmission electron microscopy.

current rate of $5 \mathrm{C}$. Even at $60 \mathrm{C}$, a very high discharge capacity of $84 \mathrm{mAh} \mathrm{g}^{-1}$ is still obtained.

\section{Other GNS composite anodes}

In the literature, there are also some reports about other types of GNS-based anode composites. Kang et al reported $\mathrm{a} \mathrm{CuCo}_{2} \mathrm{O}_{4} / \mathrm{RGO}$ composite by a solvothermal reaction in a microwave reactor, followed by calcination treatment. Porous $\mathrm{CuCo}_{2} \mathrm{O}_{4}$ nanocubes are well wrapped by RGO sheets. ${ }^{119}$ Based on the observation of the Brunauer-Emmett-Teller (BET) results, the porous $\mathrm{CuCo}_{2} \mathrm{O}_{4}$ nanocube/RGO composite exhibits a higher specific surface area $\left(34.4 \mathrm{~m}^{2} \mathrm{~g}^{-1}\right)$ 

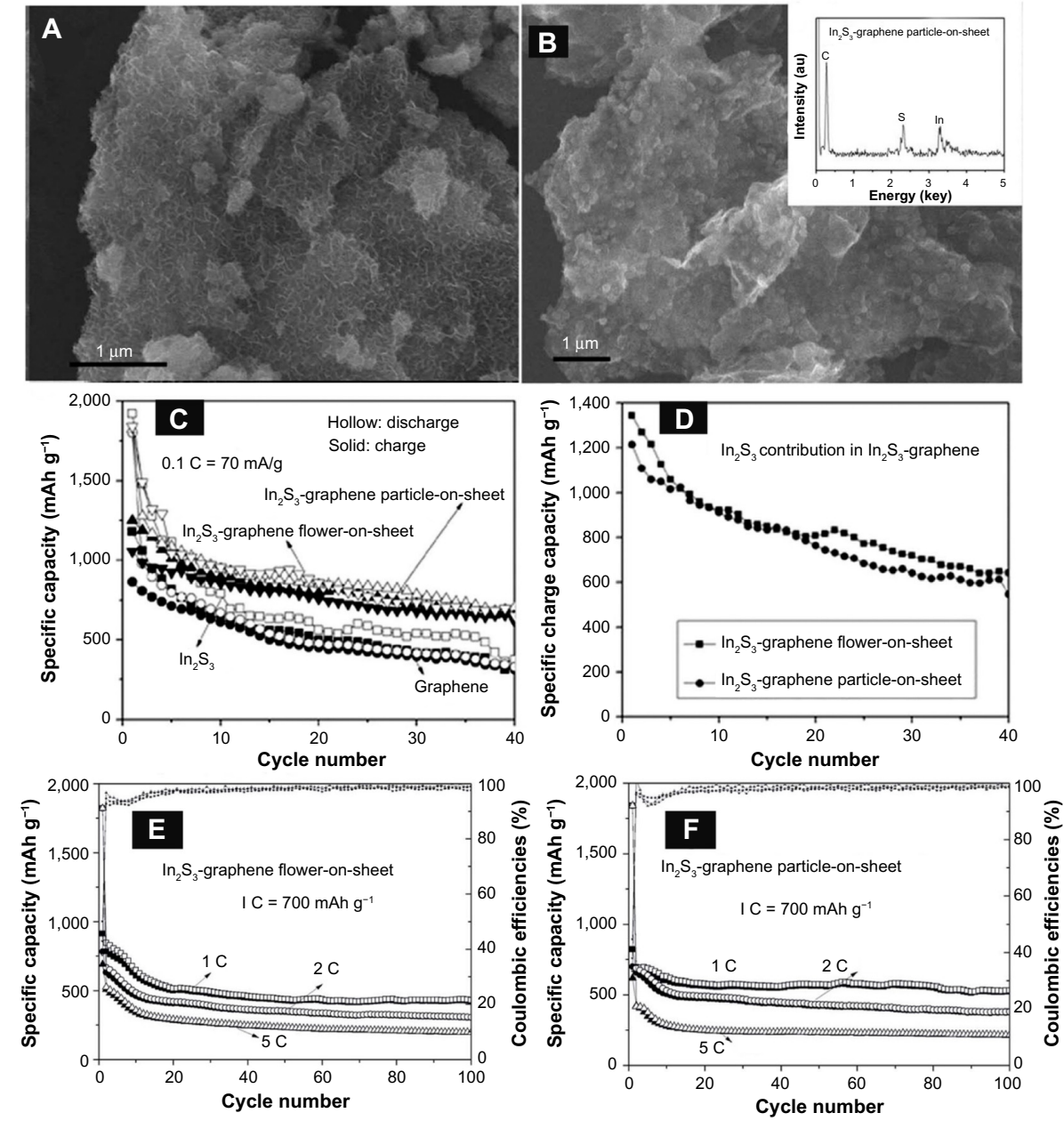

Figure 9 The $\ln _{2} \mathrm{~S}_{3}$-GNS composites and their electrochemical properties.

Notes: (A) SEM image of the $\ln _{2} \mathrm{~S}_{3}$-GNS flower-on-sheet composite, (B) SEM image of the $\ln _{2} \mathrm{~S}_{3}$-GNS particle-on-sheet composite and the inset showing the energy-dispersive $X$-ray spectrum (EDS), (C) cycling performances at $0.1 \mathrm{C}\left(70 \mathrm{~mA} \mathrm{~g} \mathrm{~g}^{-1}\right)$ and (D) $\ln _{2} \mathrm{~S}_{3}$ contribution in the composite. High-rate cycling performances: (E) In $\mathrm{S}_{3}$-GNS floweron-sheet and (F) particle-on-sheet composites at I, 2, and 5 C. Reproduced from Gu Y, Wang Y. Microwave hydrothermal growth of In $\mathrm{S}_{3}$ interconnected nanoflowers and nanoparticles on graphene for high-performance Li-ion batteries. RSC Adv. 2014;4:8582-8589, with permission from The Royal Society of Chemistry. ${ }^{114}$

Abbreviations: au, arbitrary unit; GNS, graphene nanosheets; SEM, scanning electron microscopy.

than pristine $\mathrm{CuCo}_{2} \mathrm{O}_{4}$ nanocubes $\left(10.9 \mathrm{~m}^{2} \mathrm{~g}^{-1}\right)$. This would result in the increased contact areas between the electrode and the electrolyte solution when they are used as anodes for LIBs. Such a composite exhibits a high stable
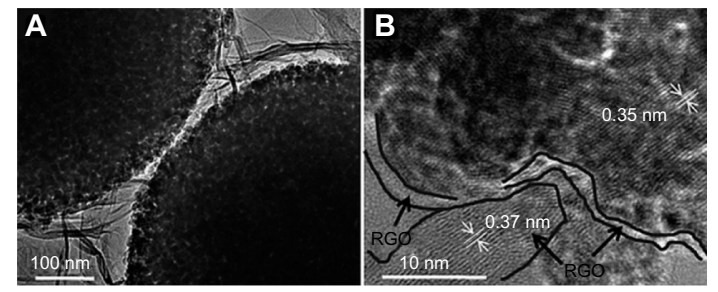

Figure 10 The $\mathrm{TiO}_{2} / \mathrm{RGO}$ composite.

Notes: (A) TEM image and (B) HRTEM image. Reproduced from Yan X, Li YJ, Du $\mathrm{F}$, et al. Synthesis and optimizable electrochemical performance of reduced graphene oxide wrapped mesoporous $\mathrm{TiO}_{2}$ microspheres. Nanoscale. 2014;6:4108-4II6 with permission of The Royal Society of Chemistry. ${ }^{118}$

Abbreviations: HRTEM, high resolution transmission electron microscopy; RGO, reduced graphene oxide; TEM, transmission electron microscopy. capacity of $\sim 570 \mathrm{mAh} \mathrm{g}^{-1}$ at $1,000 \mathrm{~mA} \mathrm{~g}^{-1}$ after 350 cycles. Impressive high-rate performance is also observed (a high capacity of $\sim 450 \mathrm{mAh} \mathrm{g}^{-1}$ even at a high current density of 5,000 $\mathrm{mA} \mathrm{g}^{-1}$ ). The morphologies and electrochemical properties of other graphene-based anode materials ${ }^{119-124}$ for LIBs synthesized via similar microwave hydrothermal/ solvothermal process in microwave oven/reactor are summarized in Table 4. Multilayer GNS were prepared by a microwave hydrothermal technique and then mixed with single-walled carbon nanotube by vacuum filtering. ${ }^{120}$ The obtained free-standing GNS-single-walled carbon nanotube film exhibits a large $d$-spacing of $0.41 \mathrm{~nm}$ and a reversible capacity of $\sim 300 \mathrm{mAh} \mathrm{g}^{-1}$ during 50 cycles. Among these reports, ${ }^{119-124} 3 \mathrm{D}$ GNS-CNT-Ni, ${ }^{123}$ and GNSCNT-Fe ${ }^{124}$ composites show good lithium ion storage properties. They were both synthesized by similar microwave 
Table 4 Summary on the morphologies and electrochemical performances of other graphene-based anode materials

\begin{tabular}{|c|c|c|c|}
\hline Composites & Morphologies & Electrochemical performances & Reference \\
\hline $\mathrm{CuCo}_{2} \mathrm{O}_{4} / \mathrm{RGO}$ & $\begin{array}{l}\text { Nanocube-on- } \\
\text { sheet }\end{array}$ & 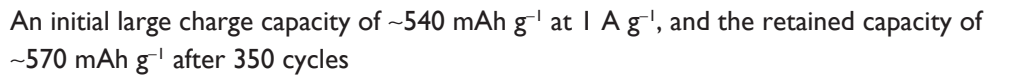 & 119 \\
\hline GNS-SWCNT & $\begin{array}{l}\text { Free-standing } \\
\text { film }\end{array}$ & 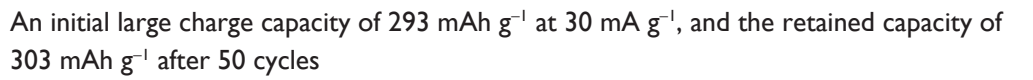 & 120 \\
\hline RGO-CNT & 3D network & $\begin{array}{l}\text { An initial charge capacity of } 682 \mathrm{mAh} \mathrm{g}^{-1} \text { at } 50 \mathrm{~mA} \mathrm{~g}^{-1} \text { and the retained capacity of } \\
298 \mathrm{mAh} \mathrm{g}^{-1} \text { after } 50 \text { cycles }\end{array}$ & 121 \\
\hline $\begin{array}{l}\mathrm{Zn}_{2} \mathrm{GeO}_{4} / \mathrm{N} \text {-doped } \\
\text { graphene }\end{array}$ & $\begin{array}{l}\text { Nanorod-on- } \\
\text { sheet }\end{array}$ & 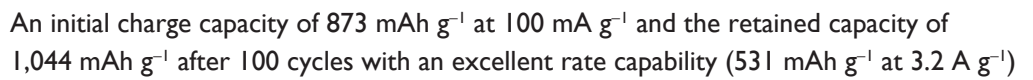 & 122 \\
\hline 3D GNS-CNT-Ni & 3D network & $\begin{array}{l}\text { An initial charge capacity of } 1,089 \mathrm{mAh} \mathrm{g}^{-1} \text { at } 100 \mathrm{~mA} \mathrm{~g}^{-1} \text { and the retained capacity of } \\
648 \mathrm{mAh} \mathrm{\textrm {g } ^ { - 1 }} \text { after } 50 \text { cycles }\end{array}$ & 123 \\
\hline 3D GNS-CNT-Fe & 3D network & A reversible capacity of $\sim 1,024 \mathrm{mAh} \mathrm{g}^{-1}$ after 40 cycles at $100 \mathrm{~mA} \mathrm{~g}^{-1}$ & 124 \\
\hline
\end{tabular}

Abbreviations: CNT, carbon nanotube; GNS, graphene nanosheets; RGO, reduced graphene oxide; SWCNT, single-walled carbon nanotube.

hydrothermal method in a microwave oven/reactor, in which vertically aligned CNTs are grown directly on graphene sheets under the catalysis of $\mathrm{Ni}$ and $\mathrm{Fe}$ nanoparticles, respectively.

\section{GNS-decorated cathodes}

Graphene is an active anode for LIBs within a comparatively low voltage window, however there is almost no lithium storage capacity for graphene at a higher voltage for cathode. Therefore graphene has been investigated with more research concerns as anodes for LIBs. In comparison, only a small amount of graphene is used for cathode composites with the purpose to improve the electrical conductivity of the cathode. And the GNS-decorated cathodes prepared by microwave-assisted methods are summarized with their morphologies and electrochemical properties in Table 5. Among various graphenebased cathodes by microwave irradiation, graphene- $\mathrm{LiFePO}_{4}$ composite has attracted more interests. ${ }^{125-127}$ As shown in Figure 11, a GNS-supported $\mathrm{LiFePO}_{4}$ nanorod composite was synthesized by a novel one-pot microwave solvothermal process within 15 minutes at a temperature below $300^{\circ} \mathrm{C}$ in an microwave synthesis system. ${ }^{125}$ The obtained graphene/ $\mathrm{LiFePO}_{4}$ nanohybrid exhibits a discharge capacity of $\sim 164$
$\mathrm{mAh} \mathrm{g}^{-1}$ (close to the theoretical value of $170 \mathrm{mAh} \mathrm{g}^{-1}$ ) at 0.1 $\mathrm{C}$ and good cyclability up to 70 cycles. $\mathrm{LiFePO}_{4} / \mathrm{C} /$ graphene composite was also reported by Shi et al. ${ }^{126}$ After a rapid, onepot, microwave-assisted hydrothermal method (15 minutes at $200^{\circ} \mathrm{C}$ ), followed by sintering at $600^{\circ} \mathrm{C}$ for 2 hours under a $\mathrm{H}_{2} / \mathrm{Ar}(5: 95, \mathrm{v} / \mathrm{v})$ atmosphere, the obtained $\mathrm{LiFePO}_{4}$ particles have sizes around $150 \mathrm{~nm}$. These particles are wrapped in crumpled micrometer-size graphene sheets. The $\mathrm{LiFePO}_{4} / \mathrm{C} /$ graphene composite exhibits obviously improved electrochemical performance with highly stable reversible capacity of $88 \mathrm{mAh} \mathrm{g}^{-1}$ at $10 \mathrm{C}$. Around $99 \%$ of the initial capacity can be retained after 40 cycles. Wang reported a similar $\mathrm{LiFePO}_{4} /$ $(\mathrm{C}+$ graphene $)$ structure. ${ }^{127}$ The composite was obtained via a direct solid-state heating reaction in a microwave oven, which delivers a large discharge capacity $\left(157.8 \mathrm{mAh} \mathrm{g}^{-1}\right)$ at $0.1 \mathrm{C}$ and more stable cycling performance than those of

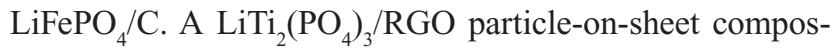
ite was synthesized via microwave hydrothermal method in a microwave oven. ${ }^{128}$ The particle-on-sheet composite can deliver a reversible capacity of $138 \mathrm{mAh} \mathrm{g}^{-1}$ at $0.1 \mathrm{C}$, and over $93.2 \%$ of its initial capacity can be retained after 100 cycles at $1 \mathrm{C}$. With the similar microwave hydrothermal method, the $\mathrm{LiMn}_{2} \mathrm{O}_{4} / \mathrm{RGO}$ nanoparticle-on-sheet composite

Table 5 Summary on the morphologies and electrochemical performances of graphene-decorated cathodes

\begin{tabular}{|c|c|c|c|}
\hline Composites & Morphologies & Electrochemical performances & Reference \\
\hline $\mathrm{LiFePO}_{4} / \mathrm{GNS}$ & Nanorod-on-sheet & A discharge capacity of $\sim 164 \mathrm{mAh} \mathrm{g}^{-1}$ at $0.1 \mathrm{C}$ and good cyclability up to 70 cycles & 125 \\
\hline $\mathrm{LiFePO}_{4} / \mathrm{C} / \mathrm{GNS}$ & Nanoparticle-on-sheet & $\begin{array}{l}\text { A high stable reversible capacity of } 88 \mathrm{mAh} \mathrm{g}^{-1} \text { at } 10 \mathrm{C} \text { and around } 99 \% \text { retained } \\
\text { after } 40 \text { cycles }\end{array}$ & 126 \\
\hline $\mathrm{LiFePO}_{4} / \mathrm{C} / \mathrm{GNS}$ & Nanoparticle-on-sheet & A high initial discharge capacity of $157.8 \mathrm{mAh} \mathrm{g}^{-1}$ at $0.1 \mathrm{C}$ and $94.7 \mathrm{mAh} \mathrm{g}^{-1}$ at $5.0 \mathrm{C}$ & 127 \\
\hline $\mathrm{LiTi}_{2}\left(\mathrm{PO}_{4}\right)_{3} / \mathrm{RGO}$ & Nanoparticle-on-sheet & $\begin{array}{l}\text { A reversible capacity of } 138 \mathrm{mAh} \mathrm{g}^{-1} \text { at a } 0.1 \mathrm{C} \text {, and retaining over } 93.2 \% \text { of its } \\
\text { initial capacity after } 100 \text { cycles at I C }\end{array}$ & 128 \\
\hline $\mathrm{LiMn}_{2} \mathrm{O}_{4} / \mathrm{RGO}$ & Nanoparticle-on-sheet & $\begin{array}{l}\text { A high specific capacity of } 137 \mathrm{mAh} \mathrm{g}^{-1} \text { at I } \mathrm{C} \text { and a remarkably high discharge } \\
\text { capacity of } 117 \mathrm{mAh} \mathrm{g}^{-1} \text { and } 101 \mathrm{mAh} \mathrm{g}^{-1} \text { at } 50 \text { and } 100 \mathrm{C} \text {, respectively }\end{array}$ & 129 \\
\hline $\mathrm{FeF}_{3} / \mathrm{RGO}$ & Nanoparticle-on-sheet & A stable capacity of $150 \mathrm{mAh} \mathrm{g}^{-1}$ retained after 50 cycles & 130 \\
\hline
\end{tabular}

Abbreviations: GNS, graphene nanosheet; RGO, reduced graphene oxide. 

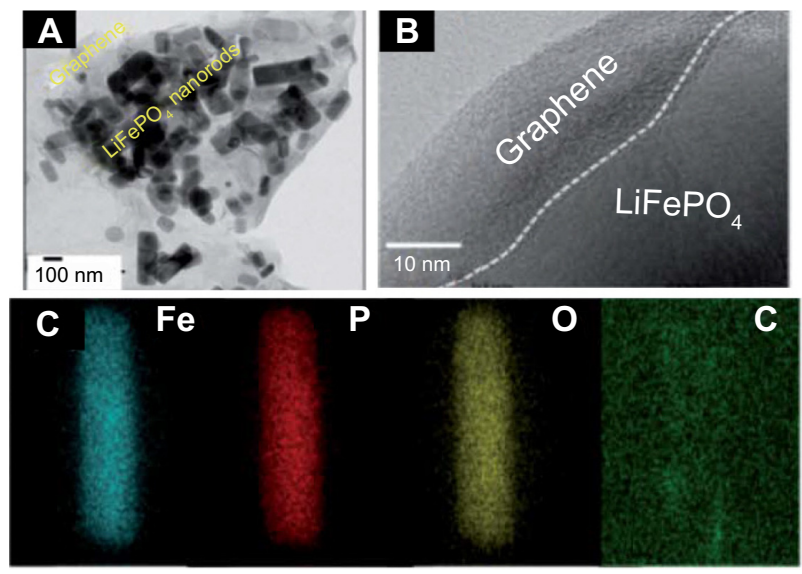

Figure I I The $\mathrm{LiFePO}_{4} / \mathrm{GNS}$ composite.

Notes: (A) TEM image, (B) HRTEM image, and (C) Elemental mapping images. Reproduced from Praneetha S, Murugan AV. A rapid, one-pot microwavesolvothermal synthesis of a hierarchical nanostructured graphene/ $\mathrm{LiFePO}_{4}$ hybrid as a high performance cathode for lithium ion batteries. RSC Adv. 201 3;3:25403-25409 with permission of The Royal Society of Chemistry. ${ }^{25}$

Abbreviations: HRTEM, high resolution transmission electron microscopy; GNS, graphene nanosheets; TEM, transmission electron microscopy.

was obtained. ${ }^{129}$ The composite can deliver a high specific capacity of $137 \mathrm{mAh} \mathrm{g}^{-1}$ at $1 \mathrm{C}$ and a remarkably high discharge capacity of $117 \mathrm{mAh} \mathrm{g}^{-1}$ and $101 \mathrm{mAh} \mathrm{g}^{-1}$ at 50 and $100 \mathrm{C}$, respectively. Moreover, $\mathrm{a} \mathrm{FeF}_{3} / \mathrm{RGO}$ composite exhibits a nanoparticle-on-sheet morphology by a microwave solvothermal process. ${ }^{130}$ It delivers a stable capacity of $150 \mathrm{mAh} \mathrm{g}^{-1}$ after 50 cycles when used as a cathode for LIBs.

\section{Conclusion}

Microwave synthesis has been demonstrated as a fast, uniform, energy-efficient, and scalable approach to prepare graphenesupported various electrodes. Representative examples such as graphene-supported transitional metal oxides, metal sulfide, tin/germanium/silicon/lithium titanium oxide based anodes, graphene-decorated lithium iron phosphate based cathodes, and some other graphene-based composite electrodes have been discussed. The fast microwave heating offers homogenous reaction environment and leads to good control of shape, size, size distribution, and agglomeration of the products. The surface functionalities on graphene can be controlled to different extents and the introduced second-phase component to graphene can be also tuned with 0D, 1D, 2D morphologies, and their stacked 3D network. These graphene-based composites usually exhibit strong synergetic effect when used for LIBs. They deliver larger capacity and better cyclability and high-rate performance compared to individual component of the composite. These improved electrochemical properties have been attributed to the preserved promising properties of graphene and the improved electrical conductivity and more stable mechanical structure of graphene-supported materials. These synthesized graphene composites with the assistance of microwave irradiation may find wide applications for other energy-storage applications such as supercapacitors and fuel cells. Furthermore, the microwave-assisted technology would be used more and more in the recent future to synthesize materials with controlled size and shape for the energy-storage application due to its simple, quick, inexpensive, uniform, and energy-efficient advantages.

\section{Acknowledgments}

The authors gratefully acknowledge the follow-up Program for Professor of Special Appointment in Shanghai (Eastern Scholar), the National Natural Science Foundation of China (51271105 and 51201095), Shanghai Municipal Education Commission (13YZ012) and Innovative Research Team (IRT13078) for financial support. The authors also thank Lab for Microstructure, Instrumental Analysis and Research Center, Shanghai University, for materials characterizations.

\section{Disclosure}

The authors report no conflicts of interest in this work.

\section{References}

1. Kim H, Hong J, Park KY, Kim H, Kim SW, Kang K. Aqueous rechargeable Li and $\mathrm{Na}$ ion batteries. Chem Rev. 2014;114:11788-11827.

2. Mai LQ, Tian XC, Xu X, Chang L, Xu L. Nanowire electrodes for electrochemical energy storage devices. Chem Rev. 2014;114: $11828-11862$

3. Wang XF, Lu XH, Liu B, Chen D, Tong YX, Shen GZ. Flexible energystorage devices: design consideration and recent progress. Adv Mater. 2014;26:4763-4782.

4. Wang CW, Wang Y, Graser J, Zhao R, Gao F, O'Connell MJ. Solutionbased carbohydrate synthesis of individual solid, hollow, and porous carbon nanospheres using spray pyrolysis. ACS Nano. 2013;7: 11156-11165.

5. Xia XH, Zhang YQ, Chao DL, et al. Solution synthesis of metal oxides for electrochemical energy storage applications. Nanoscale. 2014;6:5008-5048.

6. Mahmood N, Zhang CZ, Liu F, Zhu JH, Hou YL. Hybrid of $\mathrm{Co}_{3} \mathrm{Sn}_{2} @$ Co nanoparticles and nitrogen-doped graphene as a lithium ion battery anode. ACS Nano. 2013;7:10307-10318.

7. Gu Y, Wu FD, Wang Y. Confined volume change in Sn-Co-C ternary tube-in-tube composites for high-capacity and long-life lithium storage. Adv Funct Mater. 2013;23:893-899.

8. Zhang QF, Uchaker E, Candelariaz SL, Cao GZ. Nanomaterials for energy conversion and storage. Chem Soc Rev. 2013;42:3127-3171.

9. Zhu JX, Yang D, Yin ZY, Yan QY, Zhang H. Graphene and graphene-based materials for energy storage applications. Small. 2014;10: 3480-3498.

10. Wang DN, Yang JL, Li XF, et al. Layer by layer assembly of sandwiched graphene $/ \mathrm{SnO}_{2}$ nanorod/carbon nanostructures with ultrahigh lithium ion storage properties. Energy Environ Sci. 2013;6:2900-2906.

11. Liang MH, Zhi LJ. Graphene-based electrode materials for rechargeable lithium batteries. J Mater Chem. 2009;19:5871-5878.

12. Zhi J, Cui HL, Chen A, Xie Y, Huang FQ. Efficient highly flexible dye sensitized solar cells of three dimensional graphene decorated titanium dioxide nanoparticles on plastic substrate. J Power Sources. 2015;281: 404-410. 
13. Chang QH, Huang L, Wang JZ, et al. Nanoarchitecture of variable sized graphene nanosheets incorporated into three-dimensional graphene network for dye sensitized solar cells. Carbon. 2015;85:185-193.

14. Selopal GS, Milan R, Ortolani L, et al. Graphene as transparent front contact for dye sensitized solar cells. S Energy Mat Sol C. 2015;135: 99-105.

15. Liu CG, Yu ZN, Neff D, Zhamu A, Jang BZ. Graphene-based supercapacitor with an ultrahigh energy density. Nano Lett. 2010;10: 4863-4868.

16. Ge CY, Hou ZH, He BH, et al. Three-dimensional flower-like nickel oxide supported on graphene sheets as electrode material for supercapacitors. J Solgel Sci Technol. 2012;63:146-152.

17. Qu BH, Chen YJ, Zhang M, et al. b-Cobalt sulfide nanoparticles decorated graphene composite electrodes for high capacity and power supercapacitors. Nanoscale. 2012;4:7810-7816.

18. Zeng L, Zhao TS, An L, Zhao G, Yan XH, Jung CY. Graphene-supported platinum catalyst prepared with ionomer as surfactant for anion exchange membrane fuel cells. J Power Sources. 2015;275:506-515.

19. Liu Y, Jin XJ, Dionysiou DD, Liu H, Huang YM. Homogeneous deposition-assisted synthesis of iron-nitrogen composites on graphene as highly efficient non-precious metal electrocatalysts for microbial fuel cell power generation. J Power Sources. 2015;278:773-781.

20. Das D, Ghosh S, Basumallick I. Electrochemical studies on glucose oxidation in an enzymatic fuel cell with enzyme immobilized on to reduced graphene oxide surface. Electroanalysis. 2014;26:2408-2418.

21. Cueto M, Ocón P, Poyato JML. Comparative study of oxygen reduction reaction mechanism on nitrogen, phosphorus, and borondoped graphene surfaces for fuel cell applications. J Phys Chem C. 2015;119:2004-2009.

22. Stankovich S, Dikin DA, Dommett GHB, et al. Graphene-based composite materials. Nature. 2006;442:282-286.

23. Li XF, Hu YH, Liu J, Lushington A, Li RY, Sun XL. Structurally tailored graphene nanosheets as lithium ion battery anodes: an insigh to yield exceptionally high lithium storage performance. Nanoscale. 2013;5:12607-12615.

24. Wang J, Feng CQ, Sun ZQ, Chou SL, Liu HK, Wang JZ. In-situ one-step hydrothermal synthesis of a lead germanate-graphene composite as a novel anode material for lithium-ion batteries. Sci Rep. 2014;4:7030.

25. Vargas O, Caballero Á, Morales J, Elia GA, Scrosati B, Hassoun J. Electrochemical performance of a graphene nanosheets anode in a high voltage lithium-ion cell. Phys Chem Chem Phys. 2013;15:20444-20446.

26. Ye $\mathrm{MH}$, Dong $\mathrm{ZL}, \mathrm{Hu} \mathrm{CG}$, et al. Uniquely arranged graphene-ongraphene structure as a binder-free anode for high-performance lithiumion batteries. Small. 2014;10:5035-5041.

27. Chen SQ, Chen P, Wang Y. Carbon nanotubes grown in situ on graphene nanosheets as superior anodes for Li-ion batteries. Nanoscale. 2011;3:4323-4329.

28. Geng H, Kong SF, Wang Y. NiS nanorod-assembled nanoflowers grown on graphene: morphology evolution and Li-ion storage applications. J Mater Chem A. 2014;2:15152-15158.

29. Sun WW, Wang Y. Graphene-based nanocomposite anodes for lithiumion batteries. Nanoscale. 2014;6:11528-11552.

30. Ye JC, Charnvanichborikarn S, Worsley MA, Kucheyev SO, Wood BC, Wang YM. Enhanced electrochemical performance of ion-beam-treated 3D graphene aerogels for lithium ion batteries. Carbon. 2015;85: 269-278.

31. Cai MZ, Thorpe D, Adamson DH, Schniepp HC. Methods of graphite exfoliation. J Mater Chem. 2012;22:24992-25002.

32. Alessandro HA, Videla M, Ban S, Specchia S, Zhang L, Zhang JJ. Non-noble Fe-NX electrocatalysts supported on the reduced graphene oxide for oxygen reduction reaction. Carbon. 2014;76:386-400.

33. Pham VH, Hur SH, Kim EJ, Kim BS, Chung JS. Highly efficient reduction of graphene oxide using ammonia borane. Chem Commun. 2013;49:6665-6667.

34. Pokharel P, Truong QT, Lee DS. Multi-step microwave reduction of graphite oxide and its use in the formation of electrically conductive graphene/epoxy composites. Compos Part B Eng. 2014;64:187-193.
35. Wong CHA, Jankovský O, Sofer Z, Pumera M. Vacuum-assisted microwave reduction/exfoliation of graphite oxide and the influence of precursor graphite oxide. Carbon. 2014;77:508-517.

36. Shulga YM, Baskakov SA, Knerelman EI, et al. Carbon nanomaterial produced by microwave exfoliation of graphite oxide: new insights. RSC Adv. 2014;4:587-592.

37. Chandrasekaran S, Ramanathan S, Basak T. Microwave food processing - A review. Food Res Int. 2013;52:243-261.

38. Abubakar Z, Salema AA, Ani FN. A new technique to pyrolyse biomass in a microwave system: effect of stirrer speed. Bioresour Technol. 2013;128:578-585.

39. Motasemi F, Afzal MT. A review on the microwave-assisted pyrolysis technique. Renew Sust Energ Rev. 2013;28:317-330.

40. Mutyala S, Fairbridge C, Paré JRJ, Bélanger JMR, Ng S, Hawkins R. Microwave applications to oil sands and petroleum: a review. Fuel Process Technol. 2010;91:127-135.

41. Faraji S, Ani FN. Microwave-assisted synthesis of metal oxide/ hydroxide composite electrodes for high power supercapacitors A review. J Power Sources. 2014;263:338-360.

42. Vázquez E, Giacalone F, Prato M. Non-conventional methods and media for the activation and manipulation of carbon nanoforms. Chem Soc Rev. 2014;43:58-69.

43. Boxall DL, Lukehart CM. Rapid synthesis of Pt or Pd/carbon nanocomposites using microwave irradiation. Chem Mater. 2001;13: $806-810$.

44. Gallis KW, Landry CC. Rapid calcination of nanostructured silicate composites by microwave irradiation. Adv Mater. 2001;13:23-26.

45. Liang J, Deng ZX, Jiang X, Li FL, Li YD. Photoluminescence of tetragonal $\mathrm{ZrO}_{2}$ nanoparticles synthesized by microwave irradiation. Inorg Chem. 2002;41:3602-3604.

46. Patra CR, Alexandra G, Patra S, et al. Microwave approach for the synthesis of rhabdophane-type lanthanide orthophosphate $(\mathrm{Ln}=\mathrm{La}$, $\mathrm{Ce}, \mathrm{Nd}, \mathrm{Sm}, \mathrm{Eu}, \mathrm{Gd}$ and $\mathrm{Tb}$ ) nanorods under solvothermal conditions. New J Chem. 2005;29:733-739.

47. Zlotorzynski A. The application of microwave radiation to analytical and environmental chemistry. Crit Rev in Anal Chem. 1995;25:43-76.

48. Datta AK, Davidson PM. Microwave and radio frequency processing. J Food Sci. 2000;65:32-41.

49. Murugan AV, Muraliganth T, Manthiram A. Rapid, facile microwave-solvothermal synthesis of graphene nanosheets and their polyaniline nanocomposites for energy strorage. Chem Mater. 2009;21:5004-5006.

50. Hummers WS, Offeman RE. Preparation of graphitic oxide. JAm Chem Soc. 1958;80:1339-1339.

51. Wang Y, Liu G, An CH, et al. Bimetallic NiCo functional graphene: an efficient catalyst for hydrogen-storage properties of $\mathrm{MgH}_{2}$. Chem Asian J. 2014;9:2576-2583.

52. Chen WF, Yan LF, Bangal PR. Preparation of graphene by the rapid and mild thermal reduction of graphene oxide induced by microwaves. Carbon. 2010;48:1146-1152.

53. Hassan MAH, Abdelsayed V, Khder AERS, et al. Microwave synthesis of graphene sheets supporting metal nanocrystals in aqueous and organic media. J Mater Chem. 2009;19:3832-3837.

54. Wu ZS, Ren WC, Gao LB, Liu BL, Jiang CB, Cheng HM. Synthesis of high-quality graphene with a pre-determined number of layers. Carbon. 2009; 47:493-499.

55. Shanmugharaj AM, Choi WS, Lee CW, Ryu SH. Electrochemical performances of graphene nanosheets prepared through microwave radiation. J Power Sources. 2011;196:10249-10253.

56. Sridhar V, Jeon JH, Oh IK. Synthesis of graphene nano-sheets using eco-friendly chemicals and microwave radiation. Carbon. 2010;48: 2953-2957.

57. Khai TV, Kwak DS, Kwon YJ, et al. Direct production of highly conductive graphene with a low oxygen content by a microwave-assisted solvothermal method. Chem Eng J. 2013;232:346-355.

58. Malesevic A, Vitchev R, Schouteden K, et al. Synthesis of few-layer graphene via microwave plasma-enhanced chemical vapour deposition. Nanotechnology. 2008;19:305604. 
59. Yuan GD, Zhang WJ, Yang Y, et al. Graphene sheets via microwave chemical vapor deposition. Chem Phy Lett. 2009;467:361-364.

60. Dato A, Radmilovic V, Lee Z, Phillips J, Frenklach M. Substratefree gas-phase synthesis of graphene sheets. Nano Lett. 2008;8(7): 2012-2016.

61. Fan X, Peng W, Li Y, et al. Deoxygenation of exfoliated graphite oxide under alkaline conditions: a green route to graphene preparation. $A d v$ Mater. 2008;20:4490-4493.

62. Zhou Y, Bao QL, Tang LAL, Zhong YL, Loh KP. Hydrothermal dehydration for the "green" reduction of exfoliated graphene oxide to graphene and demonstration of tunable optical limiting properties. Chem Mater. 2009;21:2950-2956.

63. Long J, Fang M, Chen GH. Microwave-assisted rapid synthesis of water-soluble graphene. J Mater Chem. 2011;21:10421-10425.

64. Sridhar V, Lee I, Yoon HS, Chun HH, Park H. Microwave synthesis of three dimensional graphene-based shell-plate hybrid nanostructures. Carbon. 2013;61:633-639.

65. Liu XX, Zhan D, Chao DL, et al. Microwave-assisted production of giant graphene sheets for high performance energy storage applications. J Mater Chem A. 2014;2:12166-12170.

66. Eng AYS, Sofer Z, Šimek P, Kosina J, Pumera M. Highly hydrogenated graphene through microwave exfoliation of graphite oxide in hydrogen plasma: towards electrochemical applications. Chem Eur J. 2013; 19:15583-15592.

67. Abdelsayed V, Panda AB, Glaspell GP, El-Shall MS. Synthesis, passivation, and stabilization of nanoparticles, nanorods, and nanowires by microwave irradiation. In: Nagarajan R, Hatton TA, editors. Nanoparticles: Synthesis, Stabilization, Passivation, and Functionalization. Washington, DC: American Chemical Society; 2009:225-247.

68. Thomas R, Rao KY, Rao GM. Morphology and electrochemical performance of graphene nanosheet array for Li-ion thin film battery. Electrochim Acta. 2013;108:458-464.

69. Zou YQ, Wang Y.Sn@CNT nanostructures rooted in graphene with high and fast Li-storage capacities. ACS Nano. 2011;5(10):8108-8114.

70. Gerbec JA, Magana D, Washington A, Strouse GF. Microwaveenhanced reaction rates for nanoparticle synthesis. $\mathrm{J} \mathrm{Am} \mathrm{Chem} \mathrm{Soc.}$ 2005;127:15791-15800.

71. Panda AB, Glaspell G, El-Shall MS. Microwave synthesis of highly aligned ultra narrow semiconductor rods and wires. $J$ Am Chem Soc. 2006;128:2790-2791.

72. Panda AB, Glaspell G, El-Shall MS. Microwave synthesis and optical properties of uniform nanorods and nanoplates of rare earth oxides. J Phys Chem C. 2007;111:1861-1864.

73. Sun F, Huang K, Qi X, et al. Enhanced 3D hierarchical double porous $\mathrm{Co}_{3} \mathrm{O}_{4} /$ graphene architecture for superior rechargeable lithium ion battery. Ceram Int. 2014;40:2523-2528

74. Lai LF, Zhu JX, Li ZG, et al. $\mathrm{Co}_{3} \mathrm{O}_{4}$ /nitrogen modified graphene electrode as Li-ion battery anode with high reversible capacity and improved initial cycle performance. Nano Energy. 2014;3: 134-143.

75. Zhou XY, Shi JJ, Liu Y, Su QM, Zhang J, Du GH. Microwave irradiation synthesis of $\mathrm{Co}_{3} \mathrm{O}_{4}$ quantum dots/graphene composite as anode materials for Li-ion battery. Electrochim Acta. 2014;143:175-179.

76. Hsieh CT, Lin JS, Chen YF, Teng H. Pulse microwave deposition of cobalt oxide nanoparticles on graphene nanosheets as anode materials for lithium ion batteries. J Phys Chem C. 2012;116:15251-15258.

77. Chen $\mathrm{SQ}$, Wang Y. Microwave-assisted synthesis of a $\mathrm{Co}_{3} \mathrm{O}_{4}$-graphene sheet-on-sheet nanocomposite as a superior anode material for Li-ion batteries. J Mater Chem. 2010;20:9735-9739.

78. Rai AK, Anh LT, Gim J, et al. Facile approach to synthesize $\mathrm{CuO} /$ reduced graphene oxide nanocomposite as anode materials for lithiumion battery. J Power Sources. 2013;244:435-441.

79. Li N, Xiao Y, Hu CW, Cao MH. Microwave-assisted synthesis of dualconducting $\mathrm{Cu}_{2} \mathrm{O} @ \mathrm{Cu}$-graphene system with improved electrochemical performance as anode material for lithium batteries. Chem Asian J. 2013;8:1960-1965.
80. Zhou XY, Shi JJ, Liu Y, Su QM, Zhang J, Du GH. Microwave-assisted synthesis of hollow $\mathrm{CuO}-\mathrm{Cu}_{2} \mathrm{O}$ nanosphere/graphene composite as anode for lithium-ion battery. J Alloy Compd. 2014;615:390-394.

81. Sridhar V, Chun HH, Park H. 3D functional hetero-nanostructures of vertically anchored metal oxide nanowire arrays on porous graphene substrates. Carbon. 2014;79:330-336.

82. Lu LQ, Wang Y. Sheet-like and fusiform $\mathrm{CuO}$ nanostructures grown on graphene by rapid microwave heating for high $\mathrm{Li}$-ion storage capacities. J Mater Chem. 2011;21:17916-17921.

83. Zhou XY, Zhang J, Su QM, Shi JJ, Liu Y, Du GH. Nanoleaf-on-sheet $\mathrm{CuO} /$ graphene composites: Microwave-assisted assemble and excellent electrochemical performances for lithium ion batteries. Electrochim Acta. 2014;125:615-621.

84. Hu T, Xie M, Zhong J, et al. Porous $\mathrm{Fe}_{2} \mathrm{O}_{3}$ nanorods anchored on nitrogen-doped graphenes and ultrathin $\mathrm{Al}_{2} \mathrm{O}_{3}$ coating by atomic layer deposition for long-lived lithium ion battery anode. Carbon. 2014;76: 141-147.

85. Zhu XJ, Zhu YW, Murali S, Stoller MD, Ruoff RS. Nanostructured reduced graphene oxide $/ \mathrm{Fe}_{2} \mathrm{O}_{3}$ composite as a high-performance anode material for lithium ion batteries. Acs Nano. 2011;5(4):3333-3338.

86. Zhang M, Lei DN, Yin XM, et al. Magnetite/graphene composites: microwave irradiation synthesis and enhanced cycling and rate performances for lithium ion batteries. J Mater Chem. 2010;20: $5538-5543$.

87. Bhuvaneswari S, Pratheeksha PM, Anandan S, Rangappa D, Gopalan R, Rao TN. Efficient reduced graphene oxide grafted porous $\mathrm{Fe}_{3} \mathrm{O}_{4}$ composite as a high performance anode material for $\mathrm{Li}$-ion batteries. Phys Chem Chem Phys. 2014;16:5284-5294.

88. Yu SH, Conte DE, Baek S, et al. Structure-properties relationship in iron oxide-reduced graphene oxide nanostructures for $\mathrm{Li}$-ion batteries. Adv Funct Mater. 2013;23:4293-4305.

89. Zou YQ, Kan J, Wang $\mathrm{Y}_{2} \mathrm{Fe}_{2} \mathrm{O}_{3}$-graphene rice-on-sheet nanocomposite for high and fast lithium ion storage. $J$ Phys Chem C. 2011;115: 20747-20753.

90. Li L, Guo ZP, Du AJ, Liu HK. Rapid microwave-assisted synthesis of $\mathrm{Mn}_{3} \mathrm{O}_{4}$-graphene nanocomposite and its lithium storage properties. $J$ Mater Chem. 2012;22:3600-3605.

91. Noerochim L, Wang JZ, Wexler D, Chao Z, Liu HK. Rapid synthesis of free-standing $\mathrm{MoO}_{3} /$ Graphene films by the microwave hydrothermal method as cathode for bendable lithium batteries. J Power Sources. 2013;228:198-205.

92. Palanisamy K, Kim Y, Kim H, Kim JM, Yoon WS. Self-assembled porous $\mathrm{MoO}_{2}$ /graphene microspheres towards high performance anodes for lithium ion batteries. J Power Sources. 2015;275:351-361.

93. Hsieh CT, Lin CY, Chen YF, Lin JS. Synthesis of ZnO@Graphene composites as anode materials for lithium ion batteries. Electrochim Acta. 2013;111:359-365.

94. Li N, Song HW, Cui H, Yang GW, Wang CX. Self-assembled growth of Sn@CNTs on vertically aligned graphene for binder-free high Li-storage and excellent stability. $J$ Mater Chem A. 2014;2: 2526-2537.

95. Chen SQ, Wang Y, Ahn H, Wang GX. Microwave hydrothermal synthesis of high performance tin-graphene nanocomposites for lithium ion batteries. J Power Sources. 2012;216:22-27.

96. Beck FR, Epur R, Hong D, Manivannan A, Kumta PN. Microwave derived facile approach to $\mathrm{Sn} /$ Graphene composite anodes for, lithiumion batteries. Electrochim Acta. 2014;127:299-306.

97. Li N, Song HW, Cui H, Wang CX. Sn@graphene grown on vertically aligned graphene for high-capacity, high-rate, and long-life lithium storage. Nano Energy. 2014;3:102-112.

98. Thomas R, Rao KY, Rao GM. Enhanced electrochemical performance of graphene nanosheet thin film anode decorated with tin nanoparticles. Mater Express. 2014;4(1):65-71.

99. Baek S, Yu SH, Park SK, et al. A one-pot microwave-assisted nonaqueous sol-gel approach to metal oxide/graphene nanocomposites for Li-ion batteries. RSC Adv. 2011;1:1687-1690. 
100. Zhong C, Wang JZ, Chen $\mathrm{ZX}$, Liu HK. SnO -graphene composite synthesized via an ultrafast and environmentally friendly microwave autoclave method and its use as a superior anode for lithium-ion batteries. J Phys Chem C. 2011;15:25115-25120.

101. Lu HL, Li NW, Zheng MB, et al. Microwave-assisted synthesis of graphene- $\mathrm{SnO}_{2}$ nanocomposite for rechargeable lithium-ion batteries. Mater Lett. 2014;115:125-128.

102. Zhu YQ, Li C, Cao CB. Strongly coupled mesoporous $\mathrm{SnO}_{2}$-graphene hybrid with enhanced electrochemical and photocatalytic activity. RSC Adv. 2013;3:11860-11868.

103. Chen TQ, Pan LK, Liu XJ, Yu K, Sun Z. One-step synthesis of $\mathrm{SnO}_{2}$-reduced graphene oxide-carbon nanotube composites via microwave assistance for lithium ion batteries. RSC Adv. 2012;2: 11719-11724.

104. Liu LL, An MZ, Yang PX, Zhang JQ. Superior cycle performance and high reversible capacity of $\mathrm{SnO}_{2}$ /graphene composite as an anode material for lithium-ion batteries. Sci Rep. 2015;5:9055.

105. Wang DN, Li XF, Wang JJ, et al. Defect-rich crystalline $\mathrm{SnO}_{2}$ immobilized on graphene nanosheets with enhanced cycle performance for Li ion batteries. J Phys Chem C. 2012;116:22149-22156.

106. Birrozzi A, Raccichini R, Nobili F, Marinaro M, Tossici R, Marassi R. High-stability graphene nano sheets $/ \mathrm{SnO}_{2}$ composite anode for lithium ion batteries. Electrochim Acta. 2014;137:228-234.

107. Li D, Seng KH, Shi DQ, Chen ZX, Liu HK, Guo ZP. A unique sandwich-structured $\mathrm{C} / \mathrm{Ge} /$ graphene nanocomposite as an anode material for high power lithium ion batteries. J Mater Chem A. 2013;1: 14115-14121.

108. Wang CD, Chui YS, Li Y, Chen XF, Zhang WJ. Binder-free Gethree dimensional graphene electrodes for high-rate capacity Li-ion batteries. Appl Phys Lett. 2013;103:253903.

109. Maroni F, Raccichini R, Birrozzi A, et al. Graphene/silicon nanocomposite anode with enhanced electrochemical stability for lithium-ion battery applications. J Power Sources. 2014;269:873-882.

110. Wang CD, Chui YS, Ma RG, et al. A three-dimensional graphene scaffold supported thin film silicon anode for lithium-ion batteries. J Mater Chem A. 2013;1:10092-10098.

111. Shanmugharaj AM, Ryu SH. Excellent electrochemical performance of graphene-silver nanoparticle hybrids prepared using a microwave spark assistance process. Electrochim Acta. 2012;74:207-214.

112. Hsieh CT, Lin CY, Chen YF, Lin JS, Teng H. Silver nanorods attached to graphene sheets as anode materials for lithium-ion batteries. Carbon. 2013;62:109-116.

113. Chen P, Su Y, Liu H, Wang Y. Interconnected tin disulfide nanosheets grown on graphene for Li-ion storage and photocatalytic applications. ACS Appl Mater Interfaces. 2013;5:12073-12082.

114. GuY, Wang Y. Microwave hydrothermal growth of $\operatorname{In}_{2} \mathrm{~S}_{3}$ interconnected nanoflowers and nanoparticles on graphene for high-performance Li-ion batteries. RSC Adv. 2014;4:8582-8589.

115. Shi Y, Gao J, Abruña HD, et al. Rapid synthesis of $\mathrm{Li}_{4} \mathrm{Ti}_{5} \mathrm{O}_{12} /$ graphene composite with superior rate capability by a microwave-assisted hydrothermal method. Nano Energy. 2014;8:297-304.
116. Kim HK, Jegal JP, Kim JY, Yoon SB, Roh KC, Kim KB. In situ fabrication of lithium titanium oxide by microwave-assisted alkalization for high-rate lithium-ion batteries. J Mater Chem A. 2013;1: 14849-14852.

117. Kim HK, Bak SM, Kim KB. $\mathrm{Li}_{4} \mathrm{Ti}_{5} \mathrm{O}_{12}$ /reduced graphite oxide nanohybrid material for high rate lithium-ion batteries. Electrochem Commun. 2010;12:1768-1771.

118. Yan X, Li YJ, Du F, et al. Synthesis and optimizable electrochemical performance of reduced graphene oxide wrapped mesoporous $\mathrm{TiO}$ microspheres. Nanoscale. 2014;6:4108-4116.

119. Kang WP, Tang YB, Li WY, et al. Porous $\mathrm{CuCo}_{2} \mathrm{O}_{4}$ nanocubes wrapped by reduced graphene oxide as high-performance lithium-ion battery anodes. Nanoscale. 2014;6:6551-6556.

120. Zhong C, Wang JZ, Wexler D, Liu HK. Microwave autoclave synthesized multi-layer graphene/single-walled carbon nanotube composites for free- standing lithium-ion battery anodes. Carbon. 2014;66: 637-645

121. Chen TQ, Pan LK, Yu K, Sun Z. Microwave-assisted synthesis of reduced graphene oxide-carbon nanotube composites as negative electrode materials for lithium ion batteries. Solid State Ionics. 2012;229: 9-13.

122. Zou F, Hu XL, Sun YM, et al. Microwave-induced in situ synthesis of $\mathrm{Zn}_{2} \mathrm{GeO}_{4} / \mathrm{N}$-doped graphene nanocomposites and their lithium-storage properties. Chem Eur J. 2013;19:6027-6033.

123. Bae SH, Karthikeyan K, Lee YS, Oh IK. Microwave self-assembly of 3D graphene-carbon nanotube-nickel nanostructure for high capacity anode material in lithium ion battery. Carbon. 2013;64:527-536.

124. Lee SH, Sridhar V, Jung JH, et al. Graphene-nanotube-iron hierarchical nanostructure as lithium ion battery anode. ACS Nano. 2013;7(5): 4242-4251.

125. Praneetha S, Murugan AV. A rapid, one-pot microwave-solvothermal synthesis of a hierarchical nanostructured graphene/ $/ \mathrm{LiFePO}_{4}$ hybrid as a high performance cathode for lithium ion batteries. RSC Adv. 2013;3:25403-25409.

126. Shi Y, Chou SL, Wang JZ, et al. Graphene wrapped $\mathrm{LiFePO}_{4} / \mathrm{C}$ composites as cathode materials for Li-ion batteries with enhanced rate capability. J Mater Chem. 2012;22:16465-16470.

127. Wang ZZ, Guo HF, Yan P. A rapid microwave heating route to synthesize graphene modified $\mathrm{LiFePO}_{4} / \mathrm{C}$ nanocomposite for rechargeable lithium-ion batteries. Ceram Int. 2014;40:15801-15806.

128. Roh HK, Kim HK, Roh KC, Kim KB. $\operatorname{LiTi}_{2}\left(\mathrm{PO}_{4}\right)_{3} /$ reduced graphene oxide nanocomposite with enhanced electrochemical performance for lithium-ion batteries. RSC Adv. 2014;4:31672-31677.

129. Bak SM, Nam KW, Lee CW, et al. Spinel LiMn $\mathrm{O}_{4} /$ reduced graphene oxide hybrid for high rate lithium ion batteries. J Mater Chem. 2011;21:17309-17315.

130. Carlo LD, Conte DE, Kemnitz E, Pinna N. Microwave-assisted fluorolytic sol-gel route to iron fluoride nanoparticles for Li-ion batteries. Chem Commun. 2014;50:460-462.
Reports in Electrochemistry

\section{Publish your work in this journal}

Reports in Electrochemistry is an international, peer-reviewed, open access journal publishing original research, reports, reviews and commentaries on all areas of electrochemistry. The manuscript management system is completely online and includes a very quick and fair peer-

\section{Dovepress}

review system. Visit http://www.dovepress.com/testimonials.php to read real quotes from published authors. 